\title{
Global atmospheric impacts induced by year-round open water adjacent to Antarctica
}

\author{
David H. Bromwich, ${ }^{1}$ Biao Chen, and Keith M. Hines \\ Polar Meteorology Group, Byrd Polar Research Center, Ohio State University, Columbus
}

\begin{abstract}
A sensitivity study to evaluate the greatest impact that sea-ice anomalies around Antarctica could have on the global atmospheric circulation is conducted with the National Center for Atmospheric Research Community Climate Model, Version 2. A 15-year seasonal cycle simulation is performed in which all sea ice around Antarctica is removed and replaced by year-round open water at $-1.9^{\circ} \mathrm{C}$. The results are compared to a standard 15 -year seasonal cycle run with boundary conditions set for the present climate. The comparison shows that substantial changes in pressure, vertical circulation, and precipitation are found in both hemispheres as a result of Antarctic sea-ice removal. These anomalies are more significant in the southern hemisphere during May-September, whereas the anomalies are more notable in the northern hemisphere during September-November, a result which was not present in previous perpetual simulations. Convective precipitation increases and largescale precipitation decreases as the circumpolar trough moves closer to Antarctica in response to the sea-ice removal. Positive and negative anomalies form a wave-like train in the troposphere. The anomalies include the delayed onset of the winter monsoon over northern China during September. This result is in basic agreement with an observational study that found monsoon parameters are correlated with Antarctic sea-ice characteristics. In addition, the mean meridional circulation and convective precipitation have a monthly modulation of roughly 5\% in the tropics. Mechanisms for the global atmospheric propagation of the impact of the Southern Ocean surface heating anomalies are examined.
\end{abstract}

\section{Introduction}

The roles of the high latitudes in hemispheric and global climate, and particularly those associated with sea-ice variations, are receiving more scrutiny [e.g., Rind et al., 1995; Gloersen, 1995; Simmonds and Jacka, 1995; Washington and Meehl, 1996]. The important physical impact of sea ice on the climate of the atmosphere and ocean is multifaceted. Sea ice lessens the amount of solar radiation absorbed by the oceans; it serves as a strong insulator, restricting exchanges of heat, mass, momentum, and chemical constituents between ocean and atmosphere; and its formation results in changes in the ocean-mixed layer and even the deep circulation of the entire ocean [Washington and Parkinson, 1986].

Although the thickness of sea ice can influence atmospheric structure, its concentration (i.e., percent coverage) is more effective in altering the atmospheric circulation via heat fluxes across the surface-atmosphere interface [Andreas and Murphy, 1986]. In a set of perpetual simulations evaluating the sensitivity to sea ice concentration using a general circulation model (GCM), Simmonds and Budd [1991] (hereinafter referred to as SB) found large anomalies in surface heat flux locally and substantial anomalies in atmospheric circulation and precipitation over

\footnotetext{
${ }^{1}$ Also at Atmospheric Sciences Program, Department of Geography, The Ohio State University, Columbus.

Copyright 1998 by the American Geophysical Union.

Paper number 98JD00624.

0148-0227/98/98JD-00624\$09.00
}

the high and middle southern latitudes during the southern winter as the fraction of open water in the sea-ice zone was varied. In fact, these anomalies were not confined to the southern hemisphere (SH). Although SB did not articulate the interhemispheric impact, there were statistically significant anomalies of zonal wind and temperature in the middle and high latitudes of the summertime northern hemisphere $(\mathrm{NH})$. The global influence of high southern latitude forcing is supported by the recent modeling study of Lubin et al. [1998], who found that the effect of changes in Antarctic cloud radiative properties extends into the NH. Moreover, studies on the simulated climatic change due to the doubling of atmospheric $\mathrm{CO}_{2}$ show the high latitudes to be among the most sensitive regions for changes in variables such as temperature, precipitation, and snow and sea-ice coverage [Mitchell et al., 1990; Intergovernmental Panel on Climate Change, 1996]. Thus improvement in knowledge of the global response to high latitude forcing is important for both contemporary and paleoclimate applications.

The essence of the global atmospheric response to highlatitude forcing is the linkage among the high-latitude, midlatitude, and tropical circulations. Tremendous efforts have been made to understand how tropical systems and sea surface temperatures impact and regulate the middle and high latitudes on intraseasonal to interannual timescales. There is observational evidence suggesting a linkage between tropical convection and extratropical circulation on intraseasonal timescales [e.g., Knutson and Weickmann, 1987; Lau and Chan, 1985]. The large-scale circulation responds to tropical convection [Yang and Webster, 1990; Ko and Vincent, 1996; Weickmann and Kiladis, 1992], while the extratropical 
circulation can also influence the tropics [Webster and Holton, 1982; Zhang and Webster, 1992; Kiladis and Weickmann, 1992]. Held and Hoskins [1985] introduce the concept of "wave stress" to illustrate how extratropical Rossby waves radiate to the tropics and decelerate the subtropical jet and influence the location and intensity of the Hadley circulation. Hou [1998] finds that an intensification and movement of the cross-equatorial Hadley circulation can lead to midlatitude cooling and high-latitude warming in the winter extratropics in an idealized GCM. Several studies have focused on tropical linkages to persistent anomaly patterns in the SH, for example, the Pacific South American (PSA) pattern [Karoly, 1989].

Studies of the linkage of high southern latitude climate and the tropics have frequently focused on connections to the El Niño-Southern Oscillation (ENSO). Smith and Stearns [1993] expanded earlier work by M. L. Savage et al. (preprint, 1988) in correlating Antarctic observations to ENSO events. Smith and Stearns discussed anomalies of surface pressure and temperature for Antarctica that precede and follow minima in the Southern Oscillation Index. Chiu [1983], Carleton [1988, 1989], and Xie et al. [1994b] found correlations between Antarctic sea ice and ENSO events.

Researchers have also found correlations between Antarctic sea ice and NH phenomena. Xie et al. [1994a] found a lagged link between sea-ice extent in the northern and southern polar regions. Fletcher [1969] noted correlations between Antarctic sea ice and zonal indices of the SH and NH circulations. Peng and Domrös [1987] discussed connections between Antarctic sea-ice extent and distribution during 1973-1982 with the intensity and location of the subtropical high in the western Pacific. Furthermore, they found that sea ice was correlated with rainfall and runoff in the Yellow River basin in north China. Simmonds and Jacka [1995] indicate that Peng and Domrös's result must be viewed with caution, especially for studies of interannual variability, as that 10-year period included a distinct trend in the sea-ice area. Nevertheless, the results of the present modeling study generally agree with those of Peng and Domrös. While the studies of teleconnections involving Antarctic climate and sea ice in these previous studies have raised interesting questions about the mechanisms involved, clear answers are not currently available.

The present work describes the impacts on the global atmosphere induced by extreme Antarctic sea-ice anomalies in a 15-year simulation with the National Center for Atmospheric Research (NCAR) Community Climate Model, Version 2.1 (CCM2). The primary goal of this paper is to document, for seasonally varying external forcing, the significant impacts of the removal of sea ice around Antarctica on various atmospheric variables. There is abundant evidence that tropical climate variations, such as ENSO, are primary contributors to global circulation anomalies [Karoly, 1989; Chen et al., 1996; Paegle and Mo, 1988; S. R. Smith and D. H. Bromwich, preprint, 1994]. This paper considers whether variations in the polar climate forcing of the SH can provide an additional source of global circulation anomalies. Thermodynamic and dynamic mechanisms associated with the global propagation of these atmospheric perturbations are also addressed.

\section{Approach}

Here the impact of Antarctic sea ice rather than that in the Arctic is considered. This is because of the very dynamic nature of Antarctic sea ice and the fact that it is located at lower latitudes and is less confined by land masses than its northern counterpart. In the evaluation of the performances of NCAR CCM and other GCMs over the polar regions [Xu et al., 1990; Tzeng et al., 1993, 1994; Bromwich et al., 1994, 1995; Chen et al., 1995; Xu et al., 1996], it has been found that horizontal resolution is one of the major factors determining the accuracy of simulated features. Models with insufficient spatial resolution (e.g., R15, or about $4.5^{\circ}$ latitude $\times 7.5^{\circ}$ longitude) severely distort complex terrain and generate major discrepancies in and around the polar areas, especially Antarctica. The NCAR CCM2, which has a standard horizontal resolution of $\mathrm{T} 42\left(2.8^{\circ}\right.$ latitude $\times 2.8^{\circ}$ longitude), is a suitable model to perform this sensitivity study because it adequately captures most climatic features in southern high latitudes even though it has a highly simplistic treatment of sea ice [Hack et al., 1993; Tzeng et al., 1994].

In order to evaluate the greatest impact that sea-ice anomalies around Antarctica could have on the global atmospheric circulation, a sensitivity run NSIS has been conducted with CCM2 in which all sea ice in the SH was removed and replaced throughout the year by open water at $-1.9^{\circ} \mathrm{C}$. This procedure, although somewhat unrealistic, will maximize the climatic response. By amplifying the response, we reduce the masking by the time variance of the model's meteorological fields in tests of statistical significance of differences induced by the ice removal.

The sea-ice distribution varies throughout the year in the control simulation CNT, but the thickness is set to $2 \mathrm{~m}$ and the concentration is $100 \%$. Tzeng et al. [1994] find that the uniform 2-m-thick sea ice reduces energy flux from the ocean to the atmosphere and locally reduces the air temperature. The sea surface temperature and sea-ice distributions for CNT are from the standard CCM2 12-month climatology. The permanent ice shelves are retained in NSIS. Arctic sea-ice distribution and treatment for NSIS is the same as in CNT, which has the standard CCM2 boundary and initial data sets and new cloud optical properties [Kiehl, 1994]. Partially motivated by the perpetual winter simulations of SB, the 15-year simulations of CCM2 for both CNT and NSIS are integrated with seasonally varying forcing. This turns out to be an important difference in comparison with previous perpetual simulations. Mitchell and Senior [1989] have found that the change in surface roughness, in addition to the surface thermal forcing, is an important contributor to the response in these experiments. The results presented in this paper are from averages of the 15-year integrations CNT and NSIS, unless specified otherwise. The simulations begin with identical atmospheric initial conditions during September, about the time of maximum sea-ice extent. The initial conditions allow us to study the rate at which the response to the differential forcing is propagated through the atmosphere. An additional 15-year simulation NISH with both the ice shelves and sea ice removed from the $\mathrm{SH}$ was performed for a companion study [Bromwich et al., 1998]. The results of NISH were usually similar in structure to those of NSIS, but 

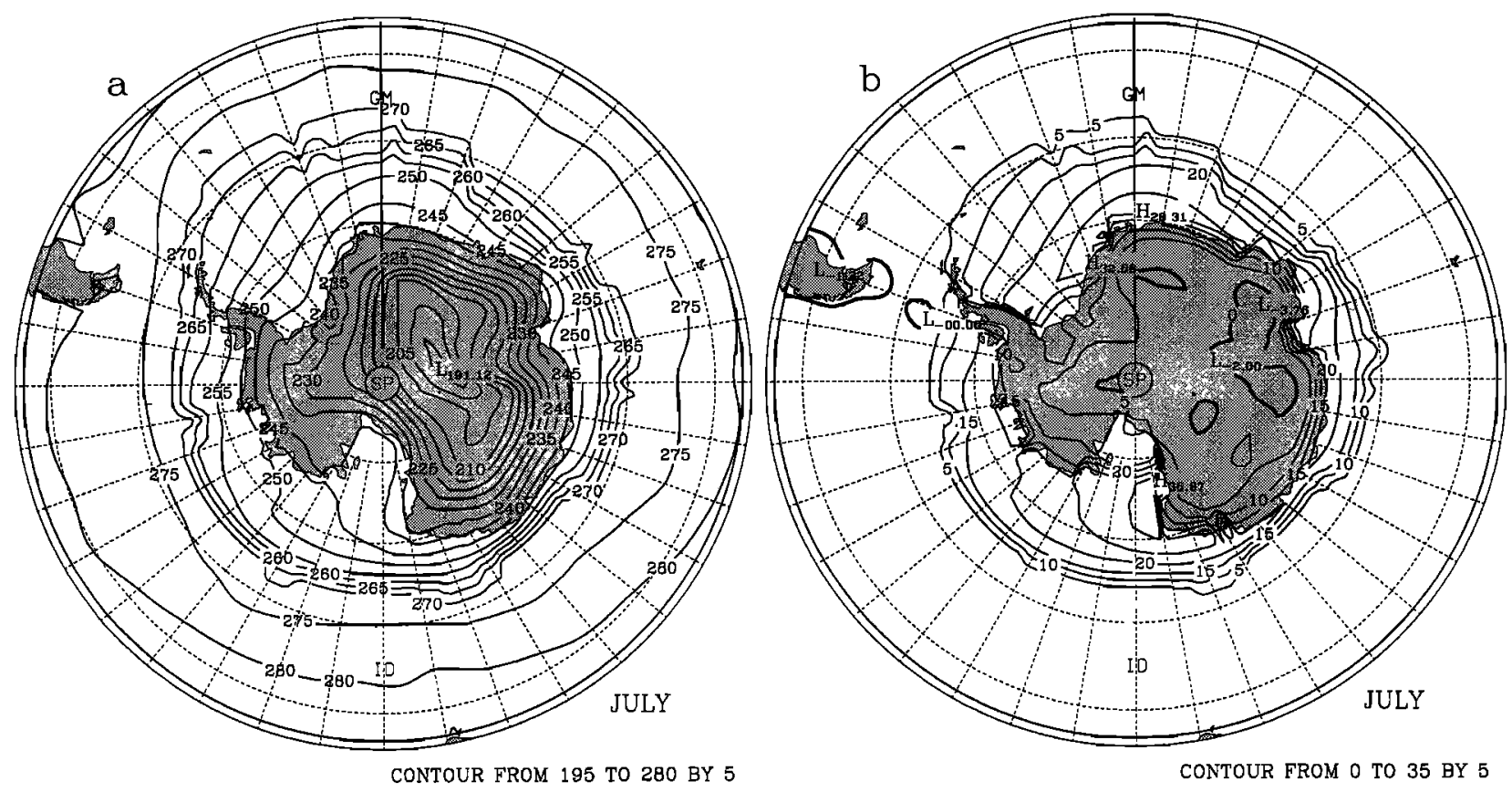

Figure 1. Time-averaged July surface temperature $(\mathrm{K})$ for (a) the control simulation CNT and (b) the difference between the simulation without sea ice in the southern hemisphere NSIS and CNT for $90^{\circ} \mathrm{S}-45^{\circ} \mathrm{S}$. The contour interval is $5 \mathrm{~K}$. The thick contour is $0 \mathrm{~K}$.

the response was amplified in the SH, especially south of $50^{\circ} \mathrm{S}$, because of the additional removal of the ice shelves.

\section{Simulation Results}

\subsection{Regional Responses}

As expected, the maximum response of surface temperature to the removal of sea ice occurs during the austral winter. Figure 1 shows the July average of model-simulated surface temperatures of CNT and the difference between NSIS and CNT for high southern latitudes. Because the sea surface temperatures outside the sea-ice zone, which are updated on the basis of climatological observations, have not changed between CNT and NSIS, the oceanic changes are purely due to the replacement of sea ice by open water at $-1.9^{\circ} \mathrm{C}$. The smallest temperature differences are to the north of the sea-ice edge, while the difference increases at higher latitudes with a maximum of $37^{\circ} \mathrm{C}$ off the Ross Ice Shelf (near $75^{\circ} \mathrm{S}, 170^{\circ} \mathrm{E}$ ). The temperature differences over the Antarctic continent, however, are remote responses to removal of sea ice. The absence of sea ice in NSIS reduces the surface temperature gradient over the Southern Ocean south of $60^{\circ} \mathrm{S}$ and intensifies the gradient for the coastal escarpment of Antarctica. The majority of the Antarctic surface area is warmed. The increase, however, is only a few degrees for the high, interior plateau.

These changes in SH surface temperature are associated with large impacts on the sensible heat flux, as maxima in water to atmosphere heat flux move closer to Antarctica with the removal of sea ice (Figure 2). Where the ice is removed in NSIS, the anomalous July fluxes are positive (upward) everywhere with typical values of $80-100 \mathrm{~W} \mathrm{~m}^{-2}$ and an extreme value of $406 \mathrm{~W} \mathrm{~m}^{-2}$ near $75^{\circ} \mathrm{S}, 170^{\circ} \mathrm{E}$ in the western Ross Sea (Figure $2 b$ ). There are negative anomalies in areas just to the north of the climatological edge of sea ice. The statistical significance of the anomalies is measured with the Student's $t$ test. For every grid point in the domain, each July (or other month) value of the 15-year simulations is taken as an independent value. Hatching in Figure $2 b$ indicates grid points where the statistically significant difference between NSIS and CNT is at a confidence level of $95 \%$ or higher.

The results shown in Figure 2 are generally consistent with the findings in SB except that the maximum values are about $25 \mathrm{~W} \mathrm{~m}^{-2}$ larger in the present case. The difference may result from the inclusion of seasonal variations in our experiment. The positive sensible heat flux anomalies probably arise because low-level air from Antarctica gains more sensible heat as it blows over the open water in NSIS than it would over the 2-m-thick sea-ice cover in CNT [Simmonds, 1981; SB]. To the north, the negative anomalies indicate a substantially increased low-level atmospheric temperature in NSIS. The latent heat flux anomalies (not shown) have a similar structure, but the magnitudes are typically one third of those for sensible heat. The latent heat release in the free atmosphere, however, may have more impact upon regional and global atmospheric circulation.

Simulated sea level pressure is shown in Figure 3. The circumpolar trough is about $3^{\circ}-5^{\circ}$ closer to Antarctica and slightly more strengthened in NSIS than in CNT. The difference field in Figure 3c shows surface pressure, not sea level pressure, to remove topographic effects. The surface pressure fall where the sea ice is removed can be easily explained as a hydrostatic response to low-level atmospheric warming from the $-1.9^{\circ} \mathrm{C}$ open water. As the Ross Sea is a 

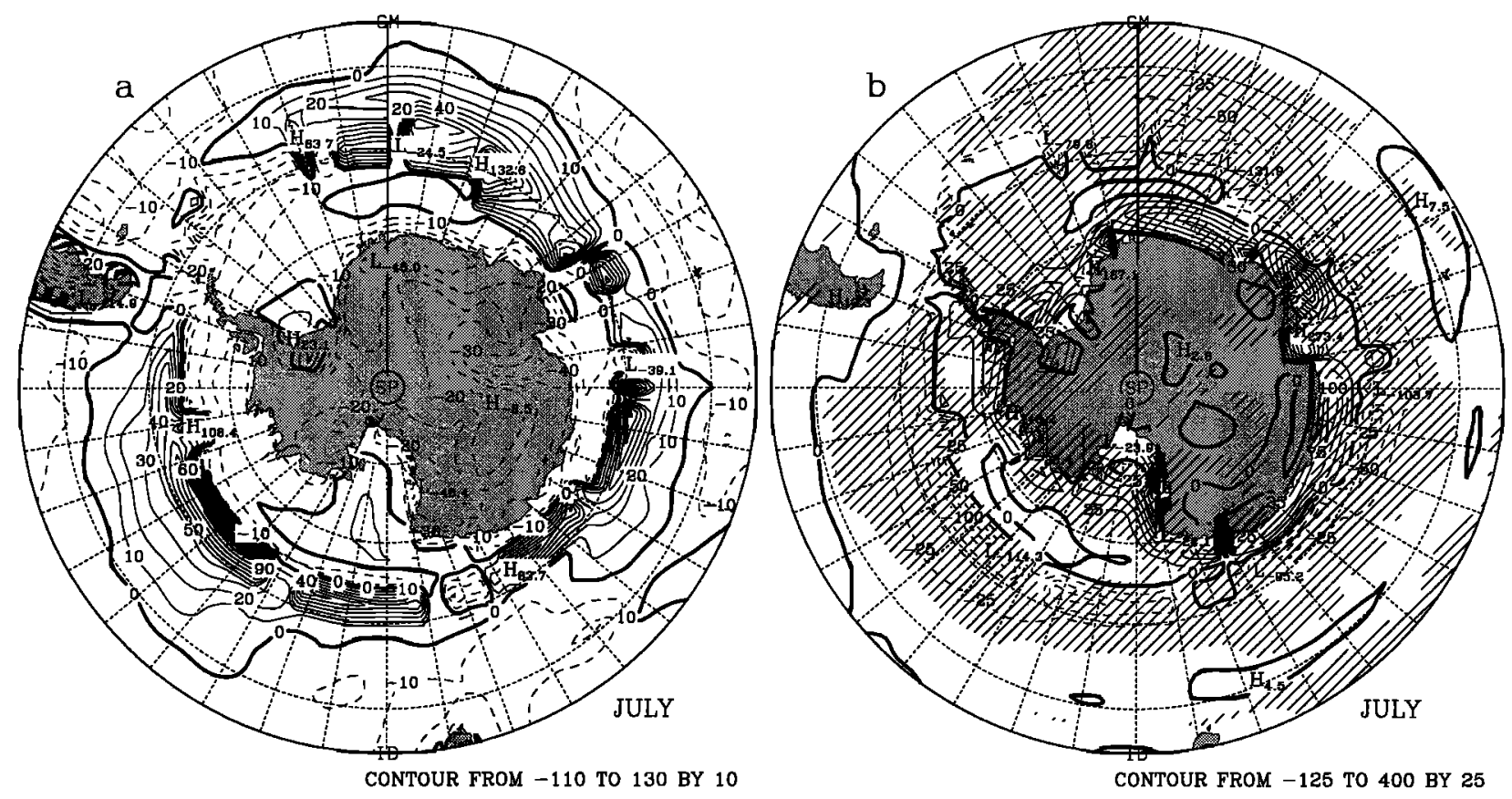

Figure 2. July surface sensible heat flux $\left(\mathrm{W} \mathrm{m}^{-2}\right)$ for (a) CNT and (b) the difference between NSIS and CNT for $90^{\circ} \mathrm{S}-45^{\circ} \mathrm{S}$. The contour interval is $10 \mathrm{~W} \mathrm{~m}^{-2}$ in Figure $2 \mathrm{a}$ and $25 \mathrm{~W} \mathrm{~m}$ in Figure $2 \mathrm{~b}$. The thick contour is $0 \mathrm{~W} \mathrm{~m}{ }^{-2}$. Differences hatched in Figure $2 \mathrm{~b}$ are statistically different from zero at the $95 \%$ confidence level.

region of very large positive temperature anomaly in Figure $1 \mathrm{~b}$, it is also a region of large negative surface pressure anomaly in Figure 3c. Hence the sea level pressure low located near $105^{\circ} \mathrm{W}$ in CNT is moved to $155^{\circ} \mathrm{W}$ in NSIS. Interestingly, the sea-ice removal has moved the low closer to its observed climatological position, as the eastward displacement of the low is a recognized error for CCM2 simulations [Tzeng et al., 1994].
The location and magnitude of the anomalies we find in the surface pressure field are similar to those obtained by SB in their $100 \%$ open water experiment. Even in their 5\% open water experiment, anomalies of several hectopascals were found, including a pressure fall of $2.6 \mathrm{hPa}$ over the northern Ross Sea and a statistically significant increase of $4.7 \mathrm{hPa}$ west of the Antarctic Peninsula. This suggests that a realistic open water fraction in the CCM2 simulations could move the

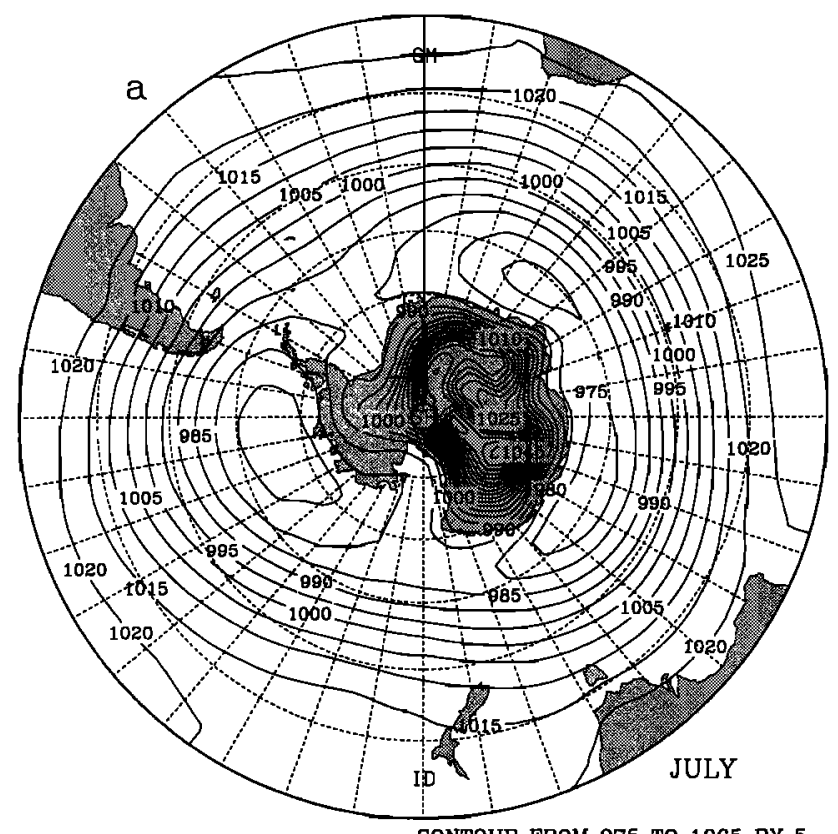

CONTOUR FROM 975 TO 1065 BY 5



Figure 3. July sea level pressure (hPa) for (a) CNT, (b) NSIS, and (c) the difference in surface pressure (hPa) between NSIS and CNT over $90^{\circ} \mathrm{S}-30^{\circ} \mathrm{S}$. The contour interval is $5 \mathrm{hPa}$ in Figures $3 \mathrm{a}$ and $3 \mathrm{~b}$ and $1 \mathrm{hPa}$ in Figure 3c. The thick contour is $0 \mathrm{hPa}$. 


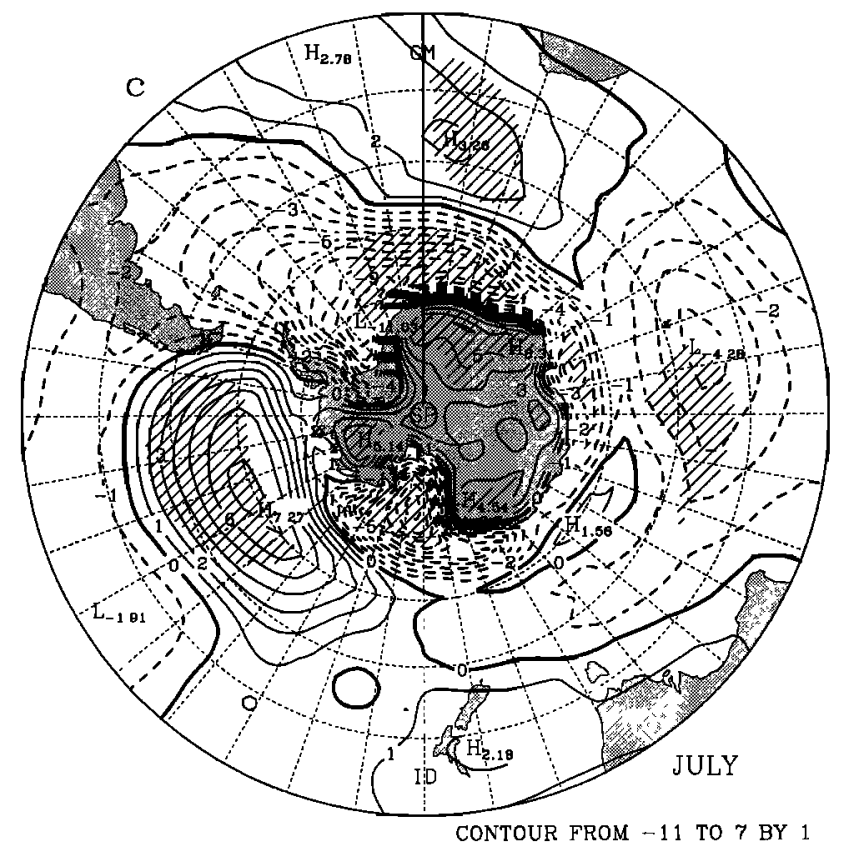

Figure 3. (continued)

surface low near West Antarctica significantly closer to its climatological position. Such a response could be considered to be a major improvement in the high southern latitude simulation by CCM2. The 2 -m-thick sea ice in CCM2 may exacerbate the consequences of the $100 \%$ sea-ice cover. Hanna [1996] suggests that Antarctic sea ice is typically 0.5$0.6 \mathrm{~m}$ thick. Thinner sea ice, in addition to leads, would increase the sensible heat flux in CCM2. Other statistically significant pressure anomalies in the $\mathrm{SH}$ are seen in Figure 3c, including a minimum within the Weddell Sea $\left(73^{\circ} \mathrm{S}, 30^{\circ} \mathrm{W}\right)$. The pressures are increased to the north of the sea-ice edge within centers in the eastern Pacific Ocean and eastem Atlantic Ocean. However, two weak ridges over the South Atlantic Ocean and Indian Ocean are significantly decreased.

An interesting response to the sea-ice removal is also seen in the surface pressure field for the austral summer. Figure 4 displays the surface pressure difference between NSIS and CNT averaged for the months December, January, and February. The removal of the sea ice has moved the circumpolar trough slightly closer to Antarctica. In the Pacific sector, the elongated positive anomaly between about $30^{\circ} \mathrm{S}$ and $60^{\circ} \mathrm{S}$ appears near where Karoly [1989] found a similarly shaped negative anomaly during ENSO warm events. In his case, the Pacific minimum was located about $30^{\circ}$ east of New Zealand, while the maximum is less than $10^{\circ}$ east of New Zealand in Figure 4.

The impacts on the precipitation from the sea surface change are illustrated in Figure 5. In CNT, precipitation generally increases to the north from values below $2 \mathrm{~cm}$ month ${ }^{-1}$ over most of Antarctica to about $10 \mathrm{~cm} \mathrm{month}^{-1}$ near $60^{\circ} \mathrm{S}$. The difference field in Figure $5 \mathrm{~b}$ indicates that precipitation in NSIS is enhanced, to local maxima in excess of $9 \mathrm{~cm}$ month $^{-1}$, over the previous sea-ice region and the Antarctic coastal areas, where, generally, the pressures fall and heat fluxes increase. Decreased precipitation is typically simulated to the north of the sea-ice zone over a width of roughly $10^{\circ}$ latitude. These features are basically consistent with the results from SB. Oglesby [1989] also found that replacing sea ice with open water increases precipitation over the continent and suggested that increased Southern Ocean sea surface temperatures might enhance Antarctic glaciation

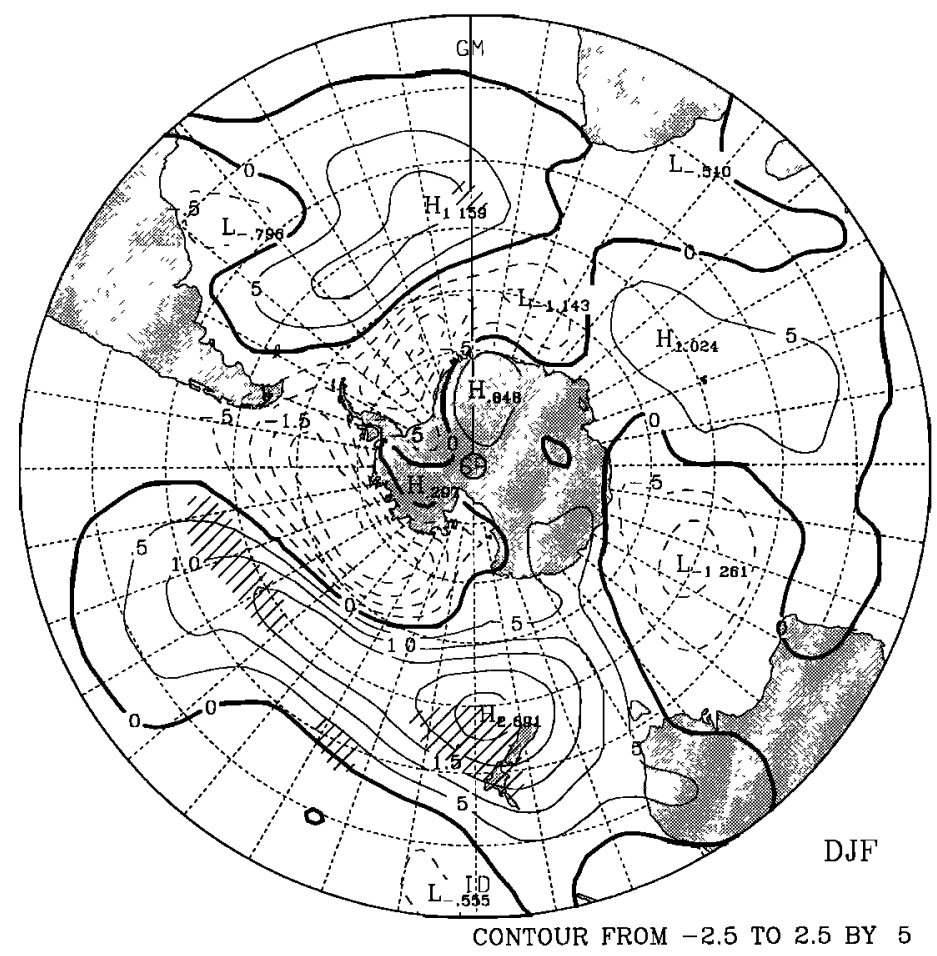

Figure 4. Difference in surface pressure (hPa) between NSIS and CNT for December, January, and February over $90^{\circ}-30^{\circ} \mathrm{S}$. The contour interval is $0.5 \mathrm{hPa}$. 

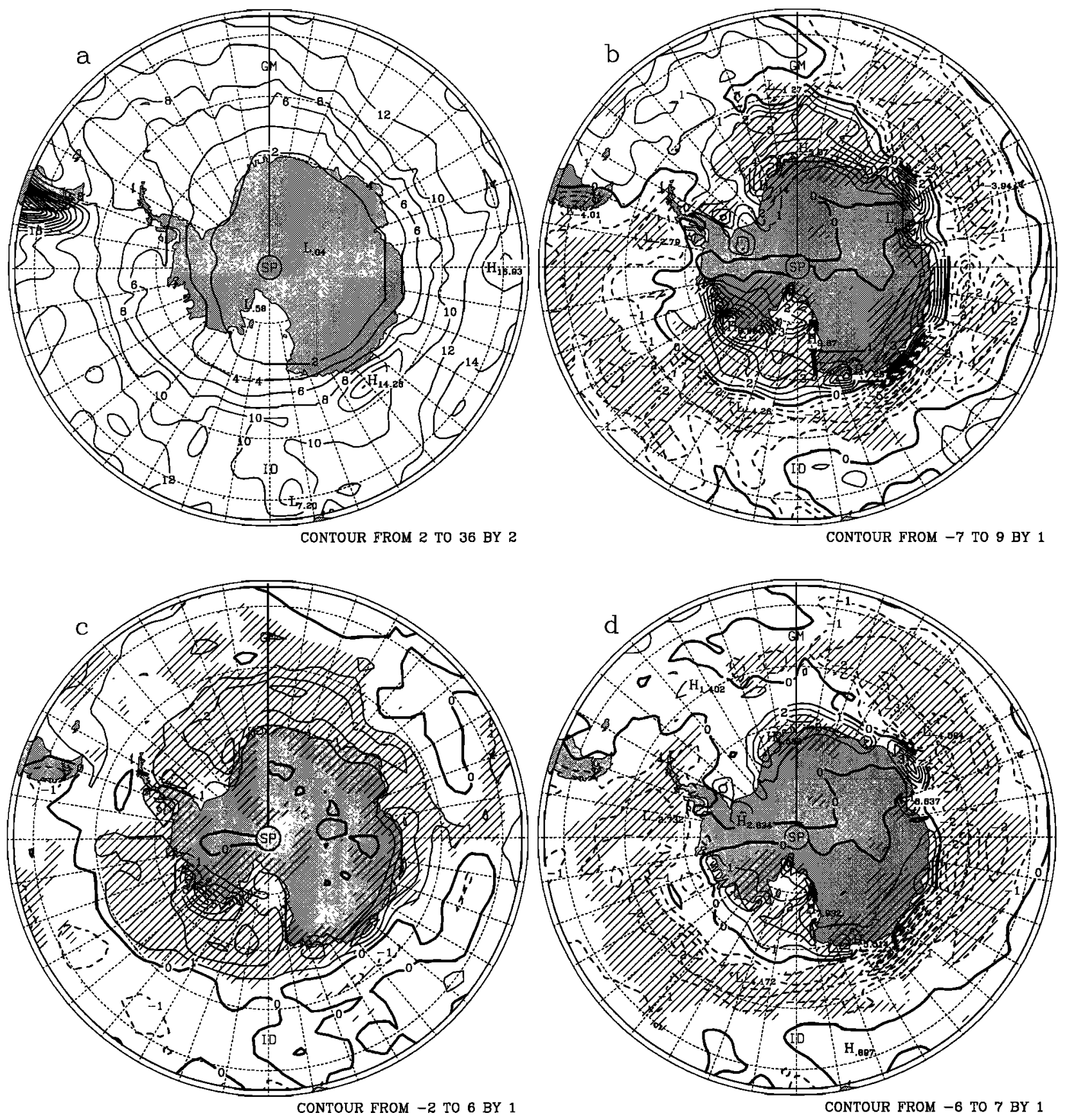

Figure 5. July precipitation (cm) for (a) CNT, (b) the difference between NSIS and CNT, (c) the difference in convective precipitation between NSIS and CNT, and (d) the difference in large-scale precipitation between NSIS and CNT over $90^{\circ}-45^{\circ} \mathrm{S}$. The contour interval is $2 \mathrm{~cm}$ in Figure $5 \mathrm{a}$ and $1 \mathrm{~cm}$ in Figures $5 \mathrm{~b}-5 \mathrm{~d}$. The thick contour is $0 \mathrm{~cm}$.

and tie up more moisture in the ice cap. However, SB suggest that too large a warming could decrease glaciation by increasing the ratio of rainfall to snowfall.

An interesting finding in the present study is shown by Figures $5 \mathrm{c}$ and $5 \mathrm{~d}$. The increase in total precipitation over the former sea-ice region is accompanied by generally increased convective precipitation south of $60^{\circ} \mathrm{S}$. The increase is typically $1-3 \mathrm{~cm} \mathrm{month}^{-1}$, with local anomalies as large as $6 \mathrm{~cm} \mathrm{month}{ }^{-1}$. Large-scale precipitation, however, is decreased in NSIS over most of the Southem Ocean. Largescale precipitation is increased in a narrow band along the
Antarctic coast. This may arise from orographic lifting of warmer, moister air in NSIS than in CNT. Otherwise, the mechanism of the precipitation over the Southern Ocean changes so that large-scale precipitation is less important and convective precipitation becomes more important as the surface is warmed, and static stability decreases. Changes in precipitation mechanisms were not discussed in previous Antarctic sea-ice removal studies.

A consequence of these heat flux anomalies (Figure 2b) can be clearly revealed in a cross section of the zonal-mean temperature field. The zonally averaged cross section of 


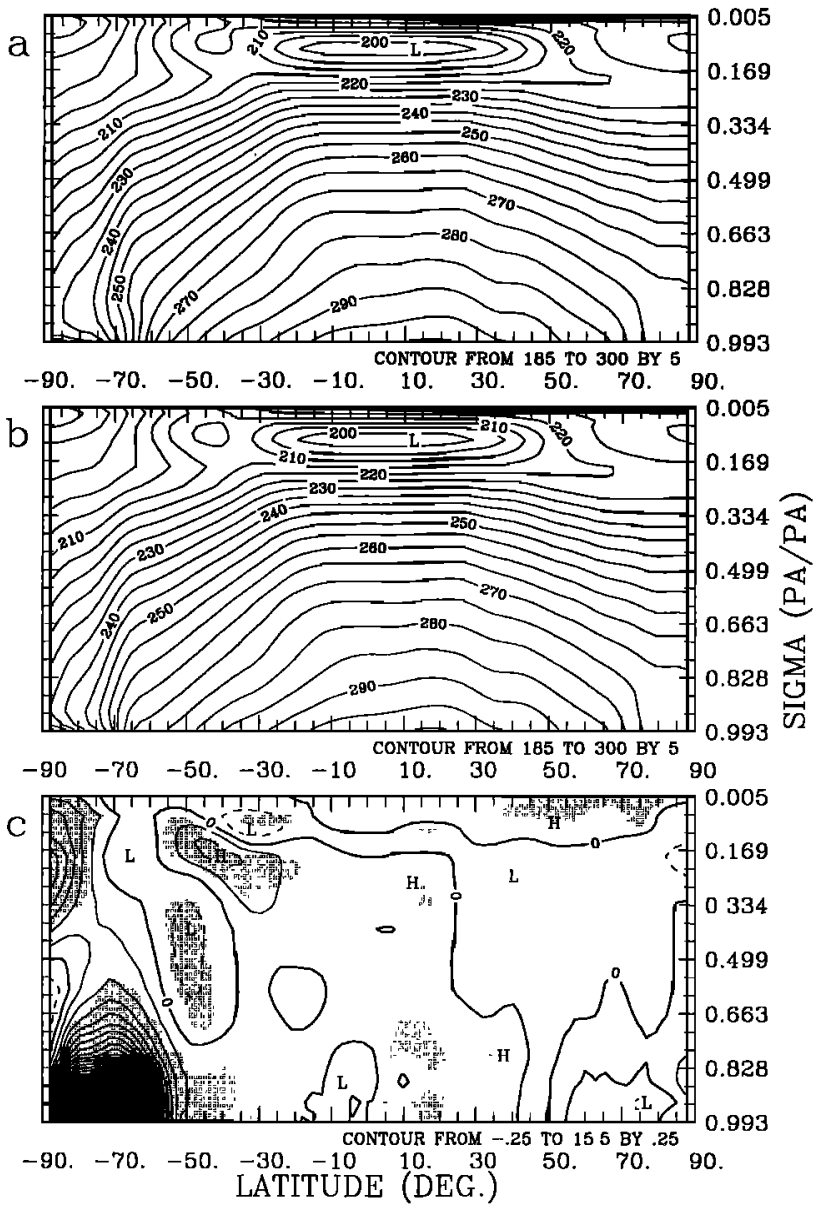

Figure 6. Zonally averaged vertical cross section of temperature (K) averaged over June, July, and August for (a) CNT, (b) NSIS, and (c) the difference between NSIS and CNT. The contour interval is $5 \mathrm{~K}$ in Figures $6 \mathrm{a}$ and $6 \mathrm{~b}$ and $0.25 \mathrm{~K}$ in Figure 6c. Statistically significant differences in Figure $6 \mathrm{c}$ are stippled.

temperature is displayed in Figure 6 averaged over the austral winter months of June, July, and August. Temperature anomalies are small except in the lower troposphere near the region of sea-ice removal (Figure $6 \mathrm{c}$ ). The direct atmospheric warming from the surface change is concentrated below the $\sigma=0.6$ level, with a surface maximum of $16 \mathrm{~K}$ near $70^{\circ} \mathrm{S}$. Indirect processes result in small but statistically significant anomalies in the SH, including warming in the polar stratosphere and midlatitude stratosphere and cooling near $50^{\circ} \mathrm{S}$ in the middle troposphere. For midlatitudes, our southern winter results vaguely resemble the results in the $50 \%$ open water case of SB (see their Figure 4). However, they find cooling in the polar stratosphere that is not present in NSIS. The small temperature response in the NH to the sea-ice removal near Antarctica is typical of the zonal mean fields for the entire year.

Zonally averaged cross sections of the zonal wind are given in Figure 7. A train of positive and negative anomalies appears in the middle-upper troposphere of the southern high and middle latitudes with a magnitude of 1-2 $\mathrm{m} \mathrm{s}^{-1}$ (Figure 7c). This anomaly pattern persists from May until October, the approximate period of maximum forcing. These indicate weakened westerlies for $50^{\circ}-75^{\circ} \mathrm{S}$ and decreased polar lowlevel easterlies. The westerly anomaly at $40^{\circ} \mathrm{S}$ results in the polar front jet merging with the subtropical jet in the upper troposphere for NSIS (Figure 7b). The anomaly pattern in the $\mathrm{SH}$, with positive and negative values spaced at $15^{\circ}-25^{\circ}$ latitude, somewhat resembles that of SB. Differences between their and our results include the polar westerly anomalies being concentrated toward the surface for NSIS and the other anomalies being $5^{\circ}-10^{\circ}$ latitude closer to the equator in SB.

There are two possible causes of these differences between SB and the results here. One could be the differences between models, such as vertical and horizontal resolution as well as physical parameterizations. The SB results are based on a GCM with R21 horizontal resolution and 9 vertical levels that are primarily concentrated in the troposphere, while the NCAR CCM2 is a much higher resolution model with T42 horizontal resolution and 18 vertical levels. Another reason could be the difference between the perpetual and seasonal cycle simulations.

An anomaly pattern for the westerly wind component very similar to that displayed in Figure 7 is found by Lubin et al. [1998] in their comparison of perpetual January simulations by CCM2 contrasting the radiative properties of $10-\mu \mathrm{m}$ ice clouds over Antarctica with those of the standard radiative properties of water clouds. This similarity in wind pattern is striking because the season is different, and the temperature anomaly pattern is highly dissimilar. Furthermore, Bromwich

a
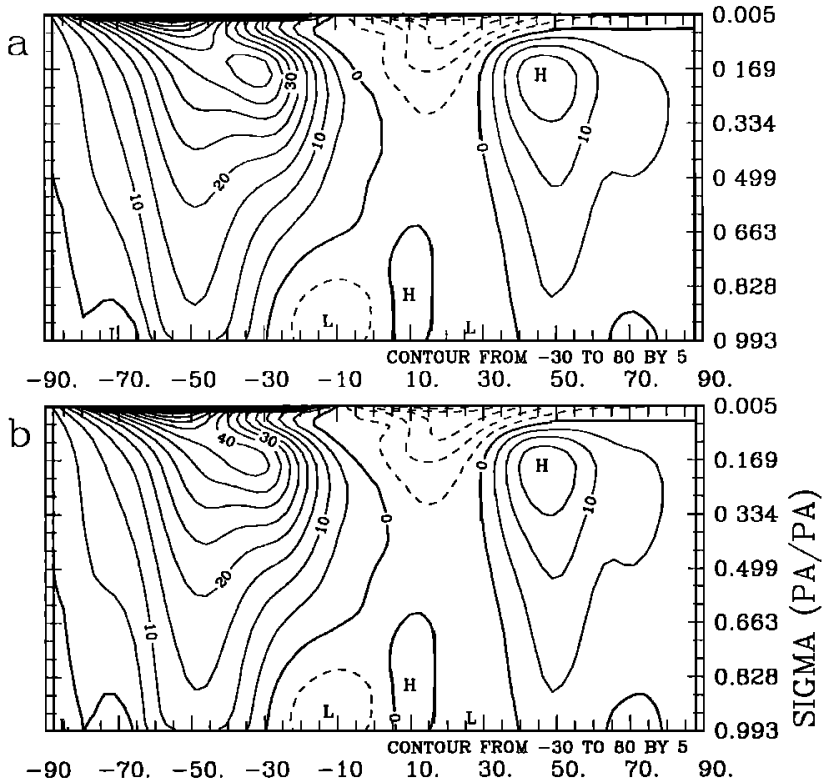

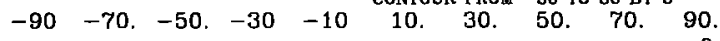

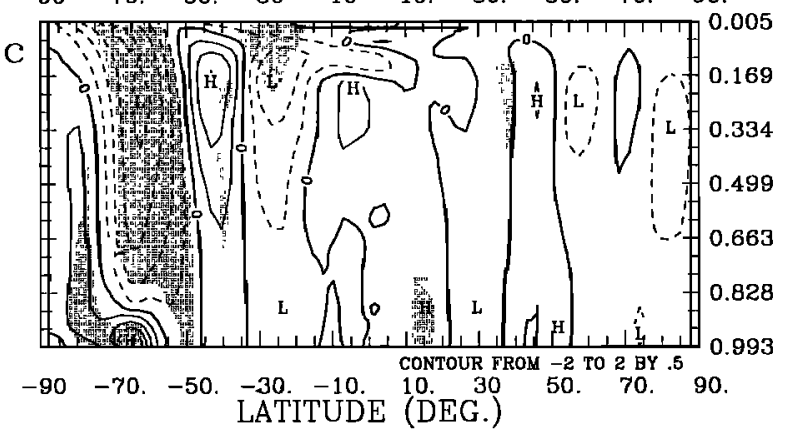

Figure 7. Same as Figure 6 except for the zonal wind $\left(\mathrm{m} \mathrm{s}^{-1}\right)$. The contour interval is $5 \mathrm{~m} \mathrm{~s}^{-1}$ in Figures $7 \mathrm{a}$ and $7 \mathrm{~b}$ and $0.5 \mathrm{~m} \mathrm{~s}^{-1}$ in Figure $7 \mathrm{c}$. 
et al. [1998] found that the zonal wind anomaly pattern for the austral winter is roughly doubled in intensity south of $50^{\circ} \mathrm{S}$ when the ice shelves are removed in addition to the sea ice being removed. This enhancement emphasizes the southerly location of the surface heating source near Antarctica as a critical factor in the response as the surface area of the ice shelves is an order of magnitude smaller than that of winter sea ice in the SH. Glowienka-Hense [1995] found a roughly similar zonal wind anomaly in her modeling study of the effect of a large polynya in the Weddell Sea. The influence of the polynya extended into the NH.

\subsection{Seasonal Cycle}

In previous studies, perpetual runs have been used to assess the sensitivity of the hemispheric circulation to changes in sea ice under the assumption that the major responses will be confined to the same hemisphere. Therefore it is interesting to examine what changes in the global circulation occur as a result of year-round removal of SH sea ice when seasonally varying forcing is applied. It is helpful here to first understand the relationship between seaice removal and the seasonal cycle of climate.

To examine the average seasonal cycle differences between CNT and NSIS, the zonal-mean precipitation is evaluated to focus on the modulation of the circumpolar trough around Antarctica and the convection in the tropics. The precipitation displayed in Figure 8 is overwhelmingly convective in the tropics with significant contributions of both convective and large-scale components in the middle to high-latitude bands in both hemispheres. Cyclone activity is particularly important for Figure 8 in the higher latitudes during winter. A prominent feature in Figure 8a for the CNT is the intertropical convergence zone (ITCZ), which oscillates between the hemispheres abruptly in early April and early November. The difference between NSIS and CNT is shown in Figure 8b. There is a pronounced decrease of precipitation in NSIS, exceeding $1 \mathrm{~cm} \mathrm{month}^{-1}$ during winter, to the north of the former sea-ice edge. The precipitation increases farther south, as already seen in Figure 5b. Modulation of the precipitation is roughly $5 \%$ in the tropics.

As shown in Figure 8b, a large increase in precipitation appears at high southern latitudes between March and October. In addition to the southward migration of the cyclone track, this local response arises because cold air blows directly off the Antarctic continent in NSIS onto the area formerly occupied by sea ice and is highly unstable. This was seen previously in the surface sensible heat flux field (Figure 2b). Latent heat release anomalies at 850 and $500 \mathrm{hPa}$ (not shown) indicate this precipitation anomaly comes from shallow and moderate depth convection.

The statistical confidence to the difference field (Figure $8 b)$ is shown in Figure 8c. The bands of increased and decreased precipitation around Antarctica and about $10^{\circ}$ farther north, respectively, are statistically significant from March to November. The weak response during the southern summer is expected, as the surface temperatures are normally near the freezing point in both CNT and NSIS in the region directly impacted by the sea-ice removal. Figure $8 \mathrm{c}$ clearly shows that the region of maximum impact on the zonal mean fields is poleward of about $50^{\circ} \mathrm{S}$. The precipitation anomaly is most significant outside of high southern latitudes during August to November, including the time of maximum SH seaice extent. During September and October, precipitation anomalies of at least $90 \%$ statistical significance are found from about $25^{\circ}$ to $40^{\circ} \mathrm{N}$. Thus NH impacts of the SH sea-ice removal are most likely to be found in the early autumn, the time of maximum perturbation forcing, as sea-ice extent is greatest at this time of year.

Figure 9 shows latitude-height cross sections of latent heating $\left(\mathrm{K} \mathrm{d}^{-1}\right)$ for October. Maximum latent heating is located at the ITCZ near $8^{\circ} \mathrm{N}$. While the maximum difference displayed in Figure 9c is where the sea ice is removed in NSIS, statistically significant differences extend north to about $45^{\circ} \mathrm{N}$ during this month. The heating is slightly

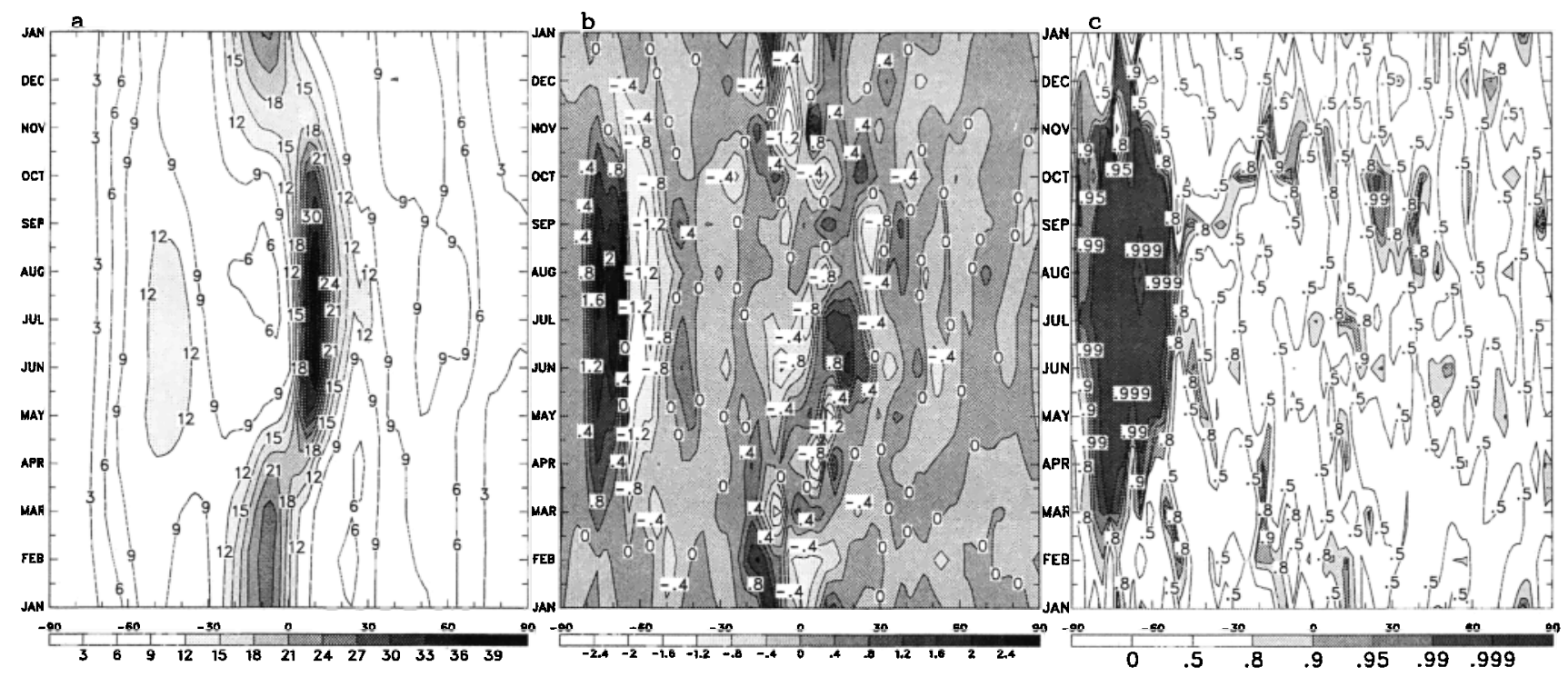

Figure 8. Gray-scale plot of the 15-year averaged zonal mean precipitation ( $\mathrm{cm}^{\text {month }} \mathrm{H}^{-1}$ ) for (a) CNT, (b) the difference between NSIS and CNT, and (c) the statistical confidence level from January to December (January is repeated at the top). The contour interval is $3 \mathrm{~cm} \mathrm{month}^{-1}$ in Figure $8 \mathrm{a}$ and $0.4 \mathrm{~cm} \mathrm{month}{ }^{-1}$ in Figure 8b. 


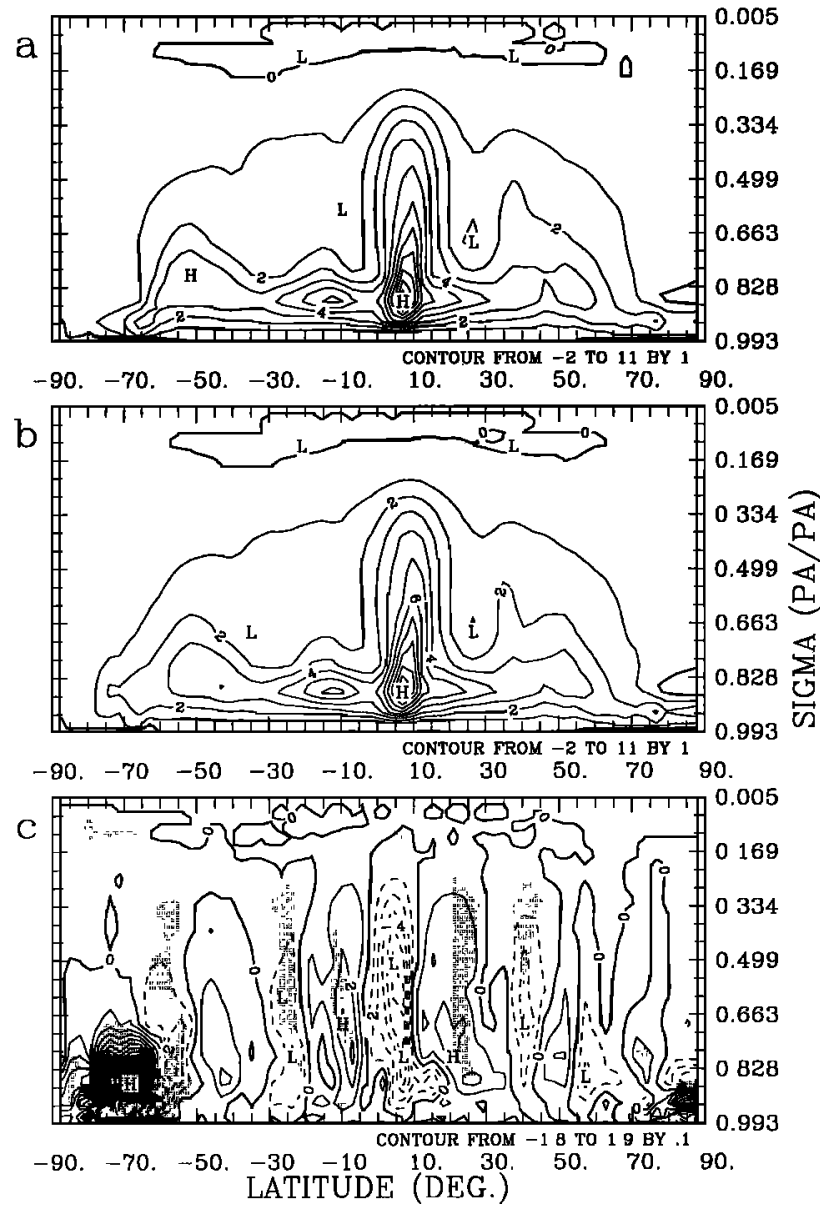

Figure 9. Same as Figure 6 except for the latent heating $\left(\mathrm{K} \mathrm{d}^{-1}\right)$ during October. The contour interval is $1 \mathrm{~K} \mathrm{~d}^{-1}$ in Figures $9 a$ and $9 b$ and $0.1 \mathrm{~K} \mathrm{~d}^{-1}$ in Figure $9 \mathrm{c}$.

reduced in the southern portion of the ITCZ for NSIS, with increased heating about $15^{\circ}$ latitude to the north and south. These two regions of increased and one of decreased latent heating, respectively, correspond to regions of increased and decreased precipitation in Figure $8 \mathrm{~b}$. Furthermore, the reduced latent heating near the equator can be compared with the zonally averaged meridional circulation displayed in Figure 10. The tropical as, cent is reduced between $0^{\circ}$ and $10^{\circ} \mathrm{N}$ in NSIS (Figure 10c).

We examine the mean meridional circulation, as it is well defined in the tropics. Changes in the tropics would be one of the key issues for exploring global influences from high southern latitudes. Wu and Brankovic [1985] calculate the zonally averaged meridional mass flux $[\chi]$ in pressure coordinates:

$$
\begin{aligned}
& \frac{\partial[\chi]}{\partial \varphi}=\frac{-2 \pi a^{2}}{g}[\omega] \cos \varphi \\
& \frac{\partial[\chi]}{\partial p}=\frac{2 \pi a}{g}[v] \cos \varphi
\end{aligned}
$$

where $\varphi$ is latitude, $p$ is pressure, $a$ is the Earth's radius, $\omega$ is vertical velocity, $v$ is meridional velocity, $g$ is gravity, and brackets indicate the zonal average. Together with the continuity equation, the mass flux can be expressed as an analytic function of $\varphi$ and $p$ :

$$
d[\chi]=\frac{\partial[\chi]}{\partial \varphi} d \varphi+\frac{\partial[\chi]}{\partial p} d p
$$

Mass flux can be found by integrating (2) with appropriate boundary conditions (details given by $W u$ and Brankovic [1985]). Positive and negative areas of meridional circulation in Figures 10, 11, and 12 indicate clockwise and counterclockwise circulation, respectively. The difference field shown in Figure 10c suggests that the influence of the sea-ice removal extends north in vertical cells about $15^{\circ}-20^{\circ}$ wide. The relative modulation of the vertical circulation is about $5-10 \%$. Interestingly, the relative modulation is not higher or larger in the $\mathrm{SH}$, nearer the removed sea-ice region, than in the NH for this month.

James [1989, equation (29)] provides a useful means to interpret the meridional circulation. Differential heating, either by diabatic processes or meridional heat flux convergence that enhances the horizontal temperature gradient will tend to produce direct meridional circulation. Thus the direct polar circulation is enhanced south of $70^{\circ} \mathrm{S}$ in NSIS. Additionally, if there is an increasing with height convergence of the flux of westerly momentum, such as one
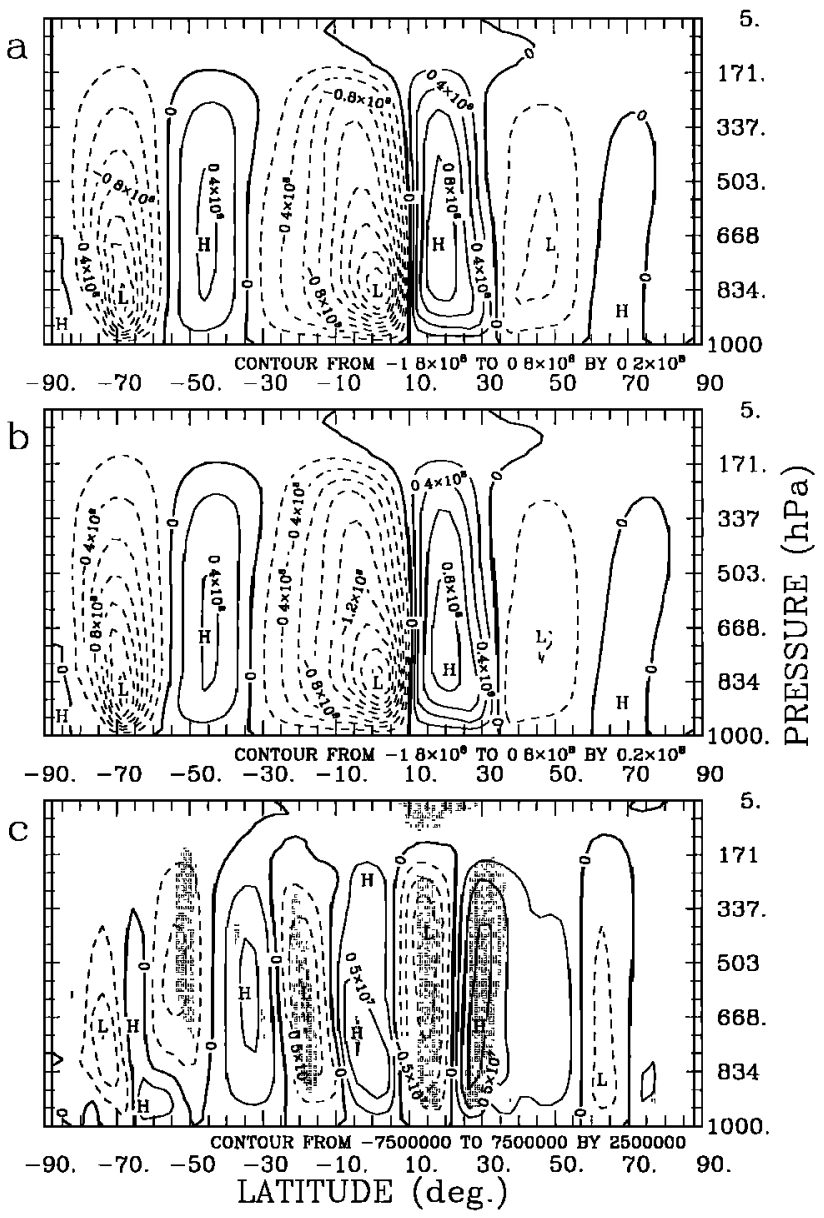

Figure 10. October meridional mass flux (ton $s^{-1}$ ) in a latitude-pressure section for (a) CNT, (b) NSIS, and (c) the difference between NSIS and CNT. The contour interval is $2 \times 10^{7}$ ton $\mathrm{s}^{-1}$ in Figures $10 \mathrm{a}$ and $10 \mathrm{~b}$ and $2.5 \times 10^{6}$ ton $\mathrm{s}^{-1}$ in Figure 10c. Statistically significant differences in Figure $10 \mathrm{c}$ are stippled. 


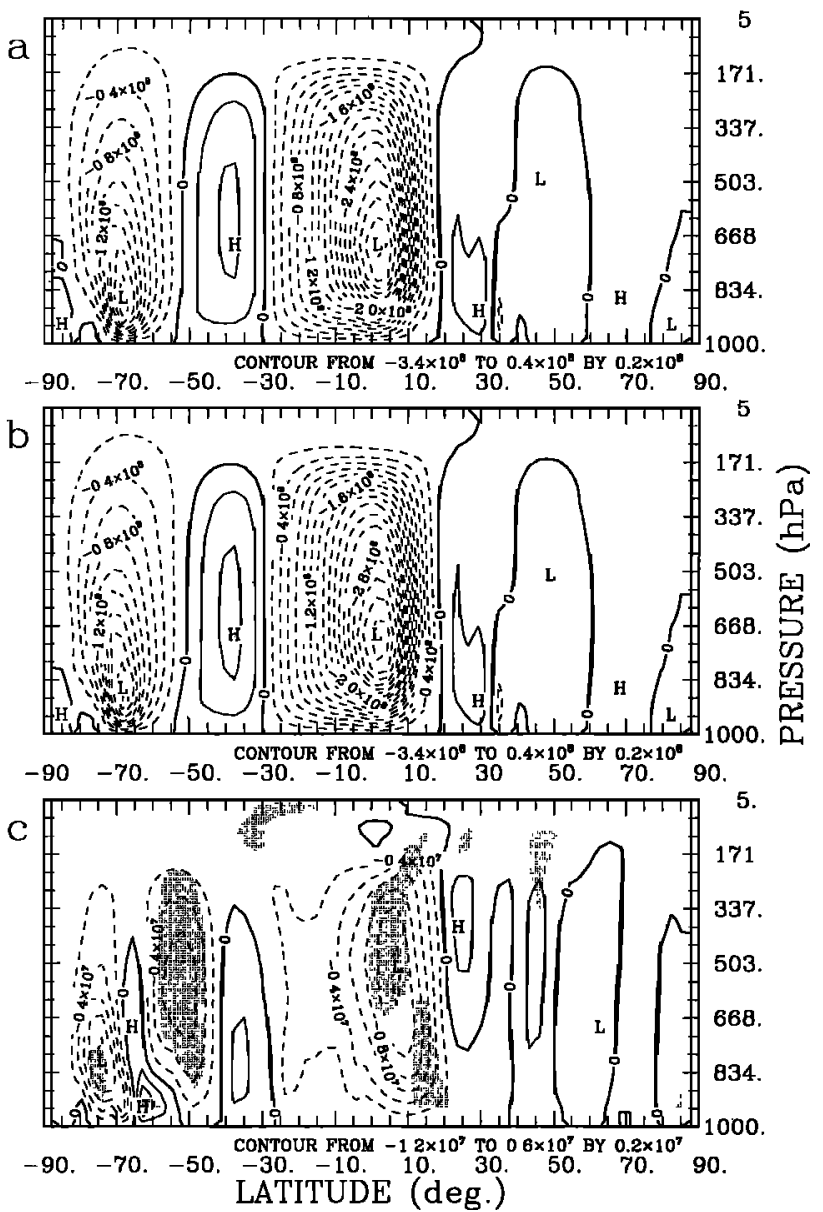

Figure 11. Same as Figure 10 except for the average of June, July, and August.

might expect for an intensifying westerly jet stream, then indirect circulation would be induced, according to James's equation (29). Consistent with this point, indirect anomaly circulation is seen between $50^{\circ} \mathrm{S}$ and $30^{\circ} \mathrm{S}$ in Figure 10c, while a westerly wind anomaly is found in the upper troposphere at about these latitudes from May to October (Figure 7c). Because James's equation is based upon quasigeostrophic theory, it should not be used to diagnose the vertical circulations in the tropics.

To gain an appreciation of the annual cycle in the NSIS simulation, Figures 11 and 12 display the seasonally averaged meridional circulation for June, July, and August and for December, January, and February, respectively. Figure 11 shows that in the austral winter, the polar direct cell is enhanced south of $70^{\circ} \mathrm{S}$ by the sea-ice removal. This is consistent with the precipitation impacts seen in Figures 5 and 8 . The Hadley cell is also intensified in winter by roughly $3 \%$. During these months, the meridional circulation in the NH is very weak in both CNT and NSIS. In the austral summer, by contrast, the surface temperature is only very slightly influenced by the sea-ice removal. Consequently, the differential forcing between NSIS and CNT is very small; hence the difference field for the zonal mean displayed in Figure $12 \mathrm{c}$ is very small in the SH polar and midlatitude regions. The anomalies in the tropics and $\mathrm{NH}$ are not statistically significant. Significant anomalies, however, are seen in the differences from the zonal means (Figure 4).

\subsection{Remote Impacts}

Figure 8 suggests that the maximum response in the $\mathrm{NH}$ will occur in autumn. Consequently, the months of September, October, and November are the focus of the $\mathrm{NH}$ evaluation. Figure 13 displays the sea level pressure pattern in the NH averaged for these three months. Statistically significant differences between NSIS and CNT are seen over the eastern and western North Pacific, eastern Canada, and eastern Europe. There is a resemblance to the negative phase of the Pacific North American (PNA) pattern, although the low along the western coast of Canada should be located slightly to the east. The negative phase of the PNA pattern is common when an ENSO warm event is not present in the tropical Pacific Ocean [Horel and Wallace, 1981]. The ENSO cycle does not occur in the CNT and NSIS simulations because of the specified climatological sea surface temperatures. There is also some resemblance to the west Pacific pattern described by Wallace and Gutzler [1981]. These surface pressure patterns in Figure 13, along with the SH pattern in Figure 4, suggest that the sea-ice removal results in known patterns of atmospheric variability. Furthermore, the response has a substantial variation in longitude. This variation is also seen in Figure 14, which shows the average latent heating between $35^{\circ}$ and $40^{\circ} \mathrm{N}$ for September. Maxima of latent heating are found over east Asia near $100^{\circ} \mathrm{E}$ in both CNT and NSIS. The maximum in

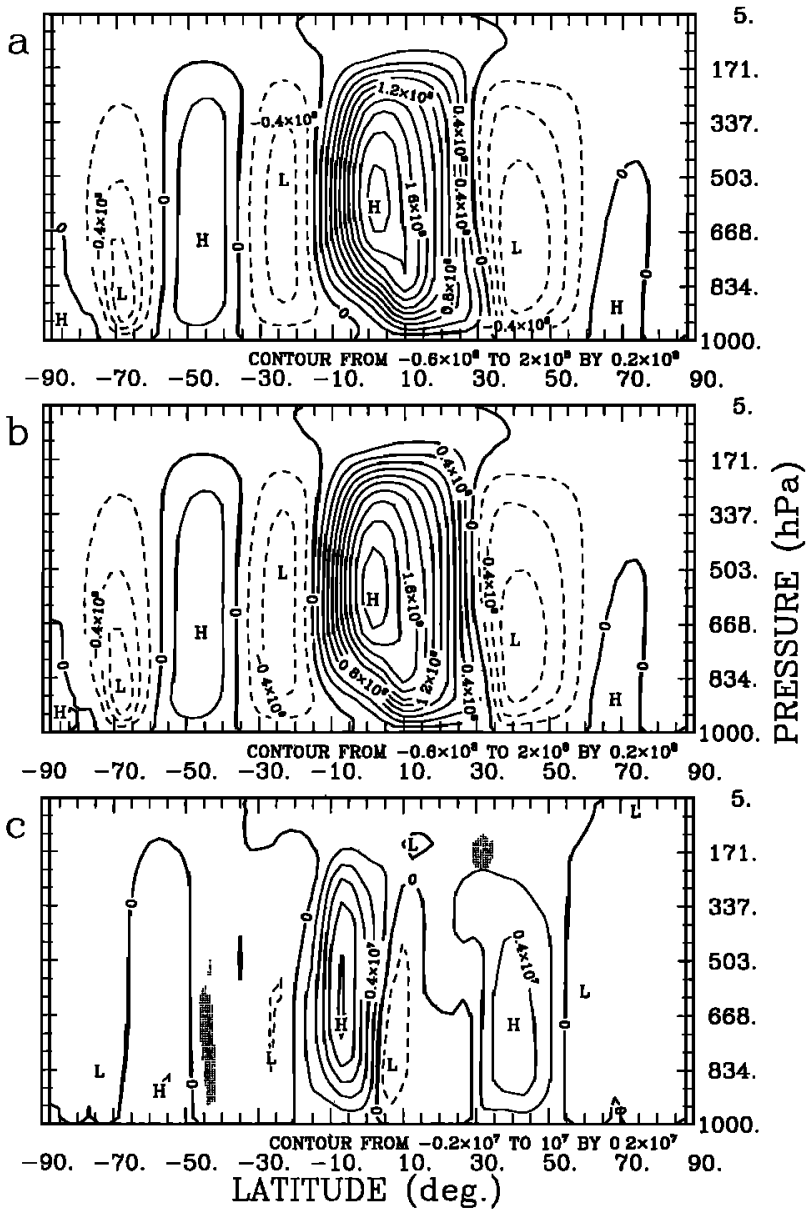

Figure 12. Same as Figure 10 except for the average of December, January, and February. 


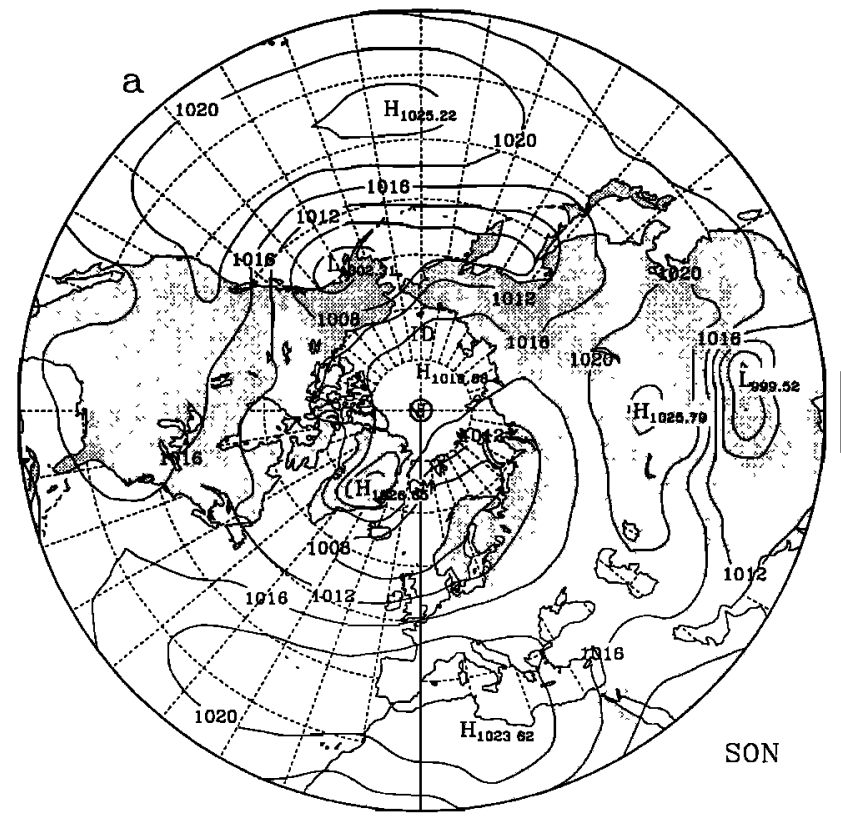

CONTOUR FROM 1000 TO 1024 BY 4

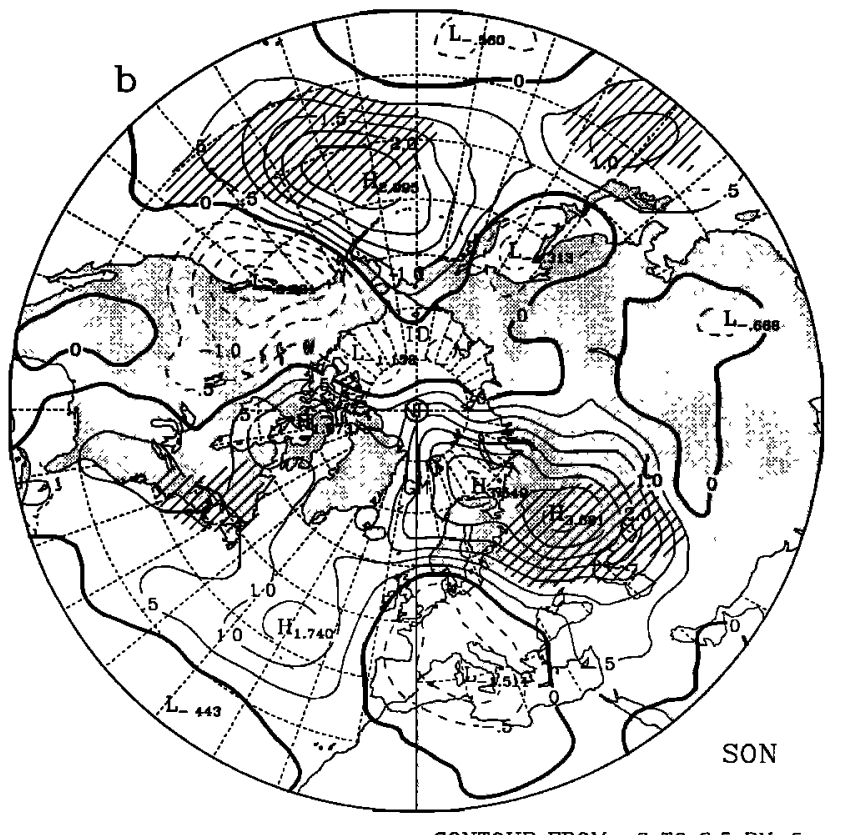

CONTOUR FROM -2 TO 3.5 BY 5

Figure 13. Sea level pressure ( $\mathrm{hPa}$ ) averaged over September, October, and November for (a) CNT and (b) the difference in surface pressure (hPa) between NSIS and CNT over $30^{\circ}-90^{\circ} \mathrm{N}$. The contour interval is $5 \mathrm{hPa}$ in Figure 13a and $1 \mathrm{hPa}$ in Figure 13b. The thick contour is $0 \mathrm{hPa}$.
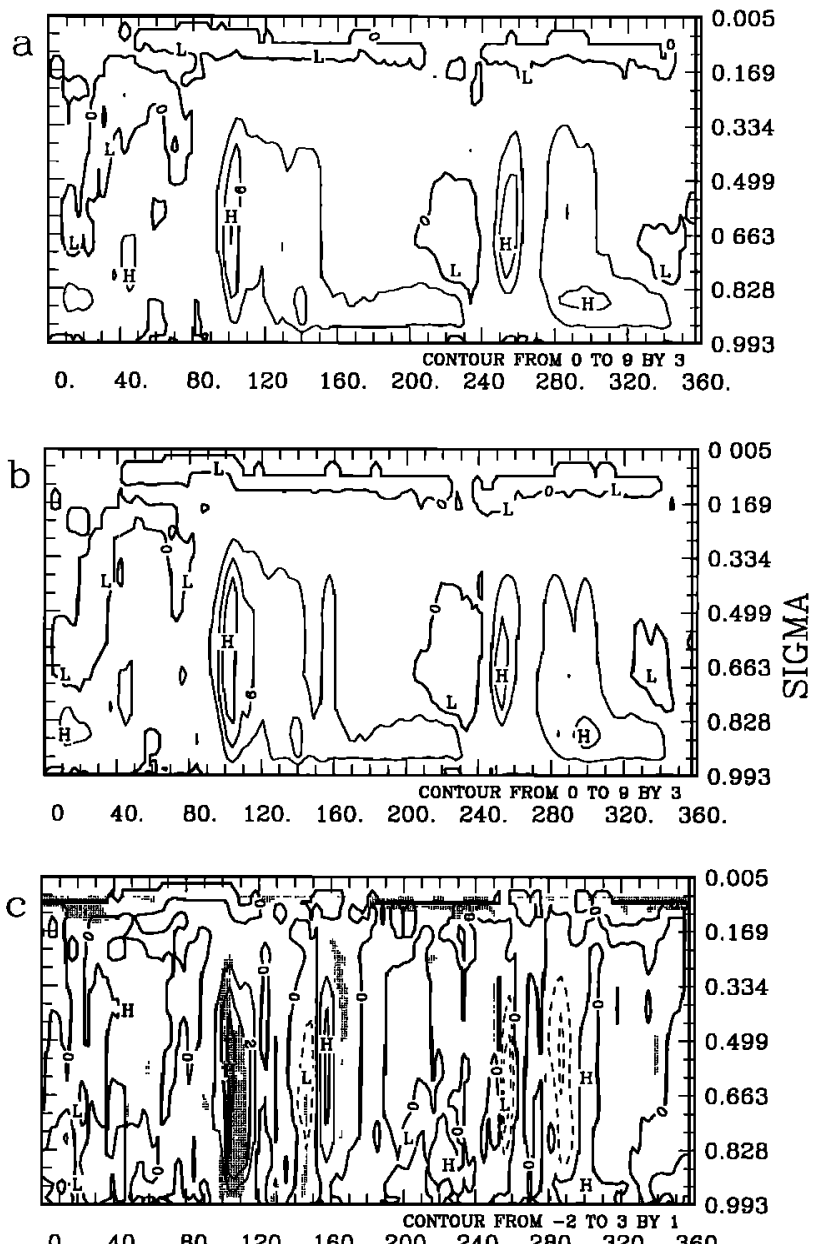

0. 40. B०. 120. 160. 200. 240. 280. 320. 360. LONGITTUDE (deg.)
NSIS is enhanced, suggesting a modification in the East Asian monsoon. To the south of this enhancement, latent heating is reduced in NSIS between $21^{\circ}$ and $32^{\circ} \mathrm{S}$ (not shown). September is normally a transitional month for the monsoon over northem China as the flow shifts from the summertime southerly pattern to the wintertime northerly pattern that is much colder and drier [Domrös and Peng, 1988]. Figure 15 shows that the September large-scale precipitation (does not include convective precipitation) is distributed more to the north over China in NSIS than in CNT, especially along the coast. The difference field in Figure $15 \mathrm{c}$ shows a maximum local increase of over $6 \mathrm{~cm}$. To the south, the large-scale precipitation is locally reduced up to $6 \mathrm{~cm}$. In the statistically significant areas over eastern China, large-scale precipitation is increased by about $60-100 \%$ or decreased by about $20-40 \%$.

Some caution is relevant here considering that $\mathrm{CCM} 2$ has a significant precipitation deficiency concerning the Asian monsoon and topography. In their evaluation of CCM2 performance, Hack et al. [1994] note the "locking" of excessive precipitation over steep topographic features. The problem is particularly notable during the summer monsoon for the high topography of the Himalayan Mountains and Tibetan Plateau. Kiehl [1994] reports that the excessive precipitation can be reduced somewhat by applying over continents the radiative properties of $5-\mu \mathrm{m}$ clouds rather than

Figure 14. September vertical cross section averaged over $35^{\circ}-40^{\circ} \mathrm{N}$ of latent heat release $\left(\mathrm{K} \mathrm{s}^{-1}\right)$ for (a) CNT, (b) NSIS, and (c) the difference between NSIS and CNT. The contour interval is $3 \mathrm{~K} \mathrm{~d}^{-1}$ in Figures $14 \mathrm{a}$ and $14 \mathrm{~b}$ and $1 \mathrm{~K} \mathrm{~d}^{-1}$ in Figure 14c. Statistically significant differences in Figure $14 \mathrm{c}$ are stippled. 


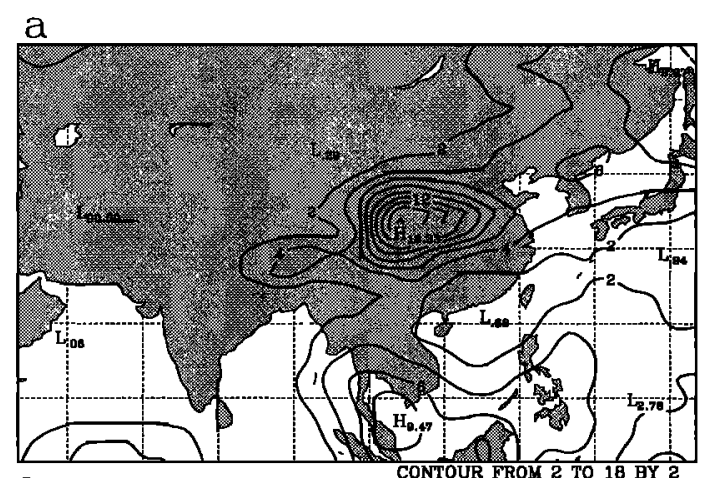

$\mathrm{b}$
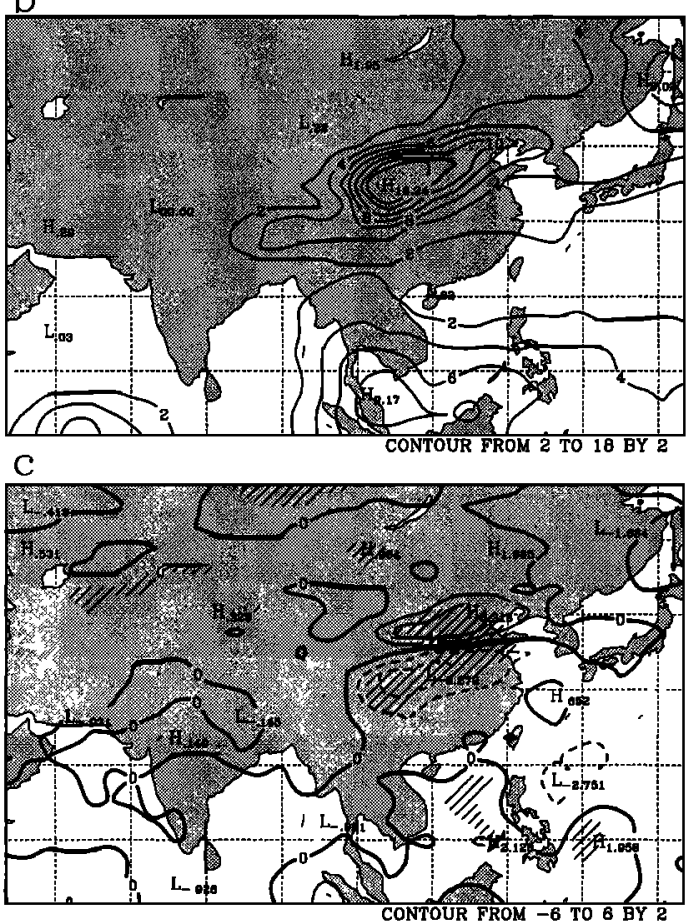

Figure 15. September large-scale precipitation (cm) over $1^{\circ}-57^{\circ} \mathrm{N}, 53^{\circ}-143^{\circ} \mathrm{E}$ for (a) CNT, (b) NSIS, and (c) the difference between NSIS and CNT. The contour interval is $2 \mathrm{~cm}$. The thick contour is $0 \mathrm{~cm}$.

those of the standard $10-\mu \mathrm{m}$ water clouds. There is an overall tendency for excessive precipitation in CCM2; however, this error has been reduced in version 2.1 of CCM2 used here with the inclusion of these improved radiative physics. Despite these deficiencies, we believe that the northward displacement of the September precipitation over China is a significant finding. The locking of precipitation to high topography is a more serious problem in the convective precipitation field (not shown), which also shows a northward migration of the rain band in NSIS. The large-scale precipitation displayed in the rain bands over northern China in Figures $15 \mathrm{a}$ and $15 \mathrm{~b}$ is clearly larger than would be realistic, as observations of total precipitation amounts for September in northem China average between 3 and $9 \mathrm{~cm}$ for numerous sites [Domrös and Peng, 1988]. Thus the difference field in Figure $15 \mathrm{c}$ is locally the same order of magnitude as the observed precipitation.

Correlations between observations of the SH sea-ice extent and northern China precipitation and river runoff have already been noted by Peng and Domrös [1987]. Furthermore, they discussed the links of the precipitation with variations in the east Asian summer monsoon and the subtropical western Pacific high. They also found that the intensity and location of the high were correlated to the extent and distribution of Antarctic sea ice. When the subtropical western Pacific high intensifies and/or moves farther west, southerly flow increases over China. Consequently, the band of highest rainfall moves farther north. The latitudinal movements of the high precipitation zone of the monsoon result in a negative correlation between rainfall in central China, including the Yangtze River watershed, and northern China, including the Yellow River watershed [Domrös and Peng, 1988]. The result of the present study that removed Antarctic sea ice is associated with a more northward location of the September rain front is consistent with the changes in precipitation and river runoff noted by Peng and Domrös for
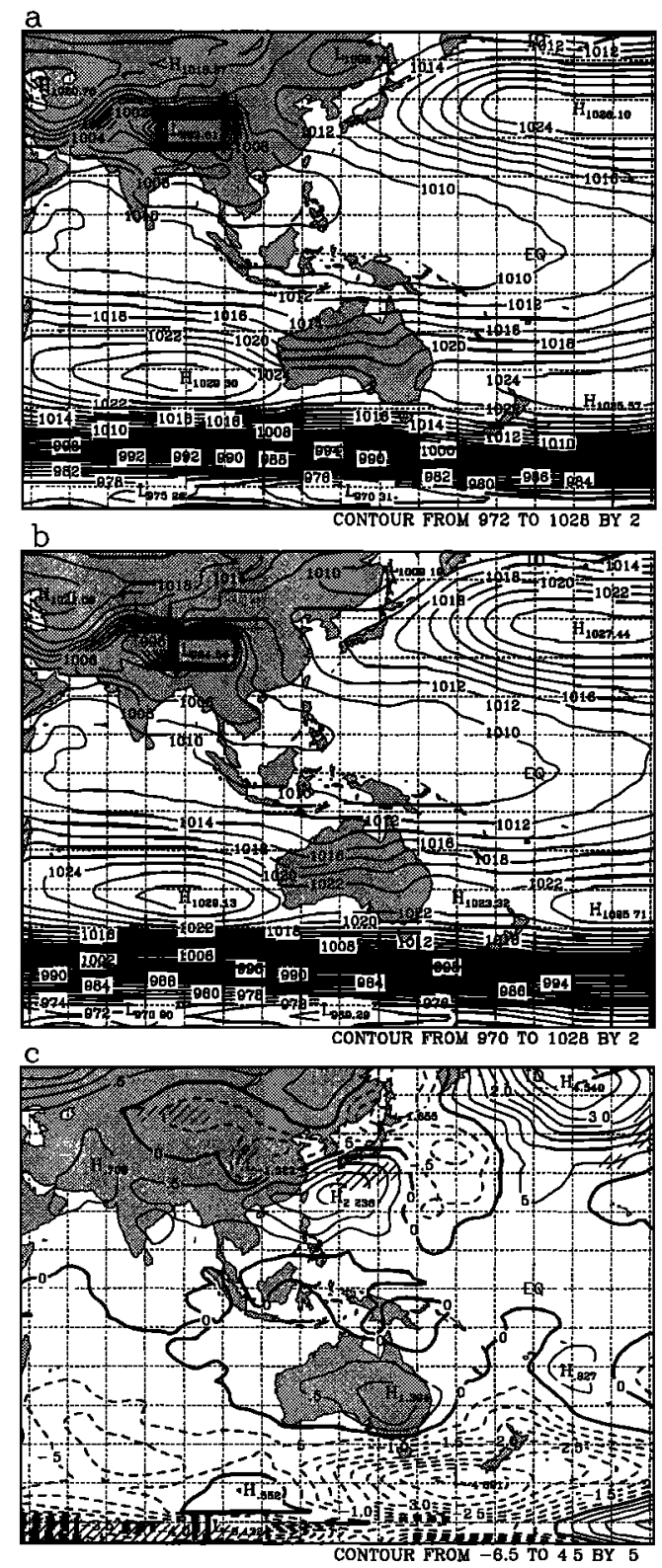

Figure 16. Same as Figure 15 except for sea level pressure $(\mathrm{hPa})$ in Figures 16a and $16 \mathrm{~b}$ and surface pressure in Figure $16 \mathrm{c}$ over $66^{\circ} \mathrm{S}-57^{\circ} \mathrm{N}, 48^{\circ} \mathrm{E}-149^{\circ} \mathrm{W}$. The contour interval is $2 \mathrm{hPa}$ in Figures $16 \mathrm{a}$ and $16 \mathrm{~b}$ and $0.5 \mathrm{hPa}$ in Figure $16 \mathrm{c}$. 
reduced sea ice. Moreover, the results of the CCM2 simulations suggest that the link is more than just passive responses to some other climatic forcing.

Figure 16 displays the September sea level pressure field. Note the statistically significant anomalies of low pressure inland over China and high pressure offshore near $130^{\circ} \mathrm{E}$ (Figure 16c). This pattern has increased the low-level southerly flow and temperature (not shown) over eastern China, consistent with the northward location rain band for NSIS in Figure 15b. Apparently, the onset of the winter monsoon circulation, characterized by cool, dry, northerly winds, occurs later in NSIS than in CNT.

Higher up in the troposphere, at the $700-\mathrm{hPa}$ level, the circulation in NSIS is associated with the more westward

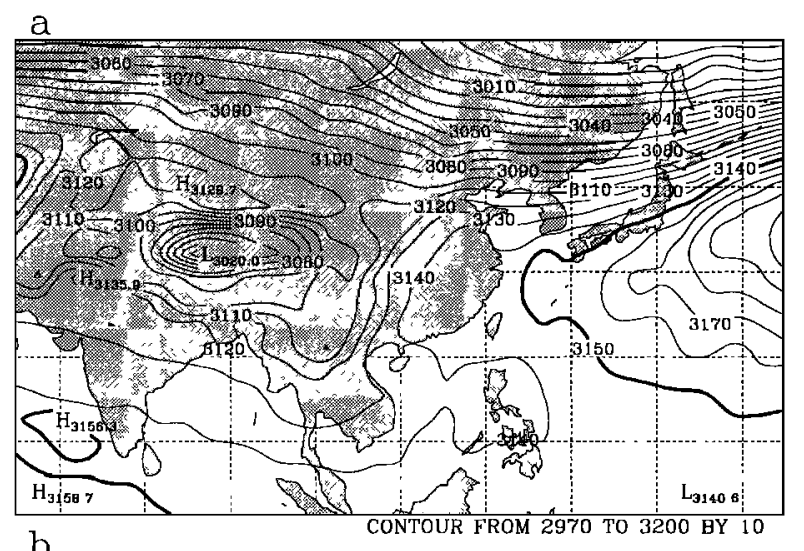

$\mathrm{b}$
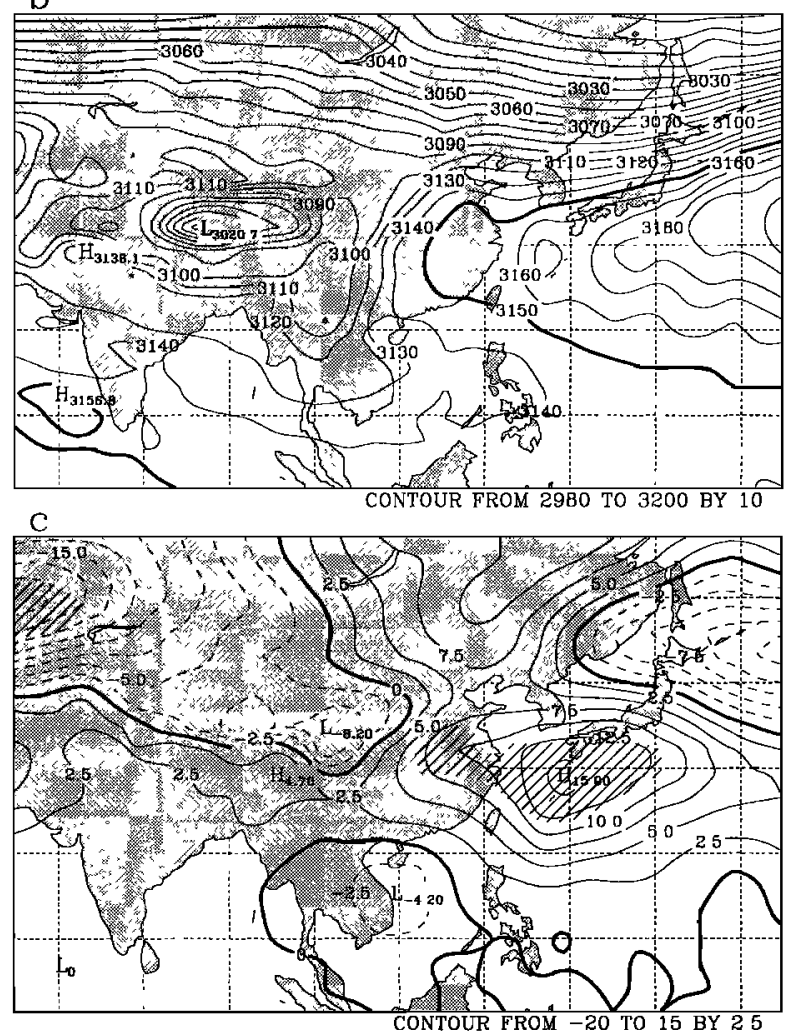

Figure 17. Same as Figure 15 except for geopotential height (gpm) at $700 \mathrm{hPa}$ for (a) CNT, (b) NSIS, and (c) the difference between NSIS and CNT over $1^{\circ}-57^{\circ} \mathrm{N}, 63^{\circ}$ $153^{\circ} \mathrm{E}$. The contour interval is $10 \mathrm{gpm}$ in Figures $17 \mathrm{a}$ and $17 \mathrm{~b}$ and $2.5 \mathrm{gpm}$ in Figure $17 \mathrm{c}$. The thick contours are 0 and $3150 \mathrm{gpm}$. location of a ridge, which extends inland near $30^{\circ} \mathrm{N}$ (Figure 17). The 3150-m contour in Figure $17 \mathrm{~b}$ reaches about $10^{\circ}$ longitude more to the west than in Figure 17a. The positive height anomaly south of Japan at $700 \mathrm{hPa}$ is larger than 15 geopotential meters (gpm). The more westward position of the subtropical ridge in the simulation without Antarctic sea ice again agrees with the trend found by Peng and Domrös [1987]. This is a significant finding, for it relates the result of our extreme experiment in which all Antarctic sea ice was removed to detected variations in the modern climate. Thus significant, nonlocal variability in climate may be associated with realistic changes in Antarctic sea ice.

Interestingly, Bromwich et al. [1998] also found an impact on the monsoon in their CCM2 simulation in which both the Antarctic sea ice and the major Antarctic ice shelves were removed. In that case, maximum NH impact occurred in late spring/early summer, about the time the summer monsoon moves north over China. The results for June in their study were generally opposite to that found for September in the present study, as the SH ice removal resulted in increased rainfall over central and southern China and reduced rainfall to the north. The removal of the Ross Ice Shelf is a particularly important forcing for Bromwich et al. [1998], as approximately two thirds of the shelf surface is between $150^{\circ}$ and $180^{\circ} \mathrm{W}$. Peng and Domrös [1987] find that sea-ice extent between these longitudes has the highest correlation with the parameters for the monsoon. The June pattern of surface pressure anomaly displayed by Bromwich et al. [1998] in their Figure 6b prompted them to suggest a link between the $\mathrm{SH}$ and $\mathrm{NH}$ with anomalous high pressure and subsidence over Australia and anomalous low pressure and rising motion centered near $23^{\circ} \mathrm{N}, 140^{\circ} \mathrm{E}$.

A link between the SH and the east Asian monsoon is reasonable, as the low-level $(\sigma=0.970)$ meridional flow for the NH summer months and September is northward and about $1-5 \mathrm{~m} \mathrm{~s}^{-1}$ in amplitude in the region from the eastern Indian Ocean and Australia northward into southern Asia and reaching as far north as $40^{\circ} \mathrm{N}$ in eastern China. Crosshemispheric influence in this region is supported by the study of Rodwell [1997]. He found that negative potential vorticity advected northward from the Indian Ocean can modulate the monsoon rainfall over India. Furthermore, he noted that the entire Asian monsoon, not just the component over India, was influenced by potential vorticity intrusions from the southern hemisphere. In the present case, the anomalous September monsoon patterns between NSIS and CNT appear to be more complicated than the June patterns shown by Bromwich et al. [1998]. Figure 18 shows the surface pressure anomaly also displayed in Figure $16 \mathrm{c}$ along with arrows to show the NSISCNT difference in velocity at $\sigma=0.970$ and pluses and minuses to indicate the location of statistically significant upward and downward vertical velocity, respectively, at the $\sigma=0.695$ level (near $700 \mathrm{hPa}$ ). Anomalous descent is located over Australia as in Bromwich et al. [1998]. Unlike their results, however, a high surface pressure anomaly is present near $23^{\circ} \mathrm{N}, 130^{\circ} \mathrm{E}$ in Figure 18. An anomalous northward wind component of about $0.5 \mathrm{~m} \mathrm{~s}^{-1}$ extends from the region of subsidence over central Australia to the region of ascent just east of the Philippines. The low-level convergence near the region of statistically significant ascent is enhanced by anomalous low-level southwestward winds of $2-3 \mathrm{~m} \mathrm{~s}^{-1}$ from the clockwise flow spiraling out of the high-pressure anomaly 


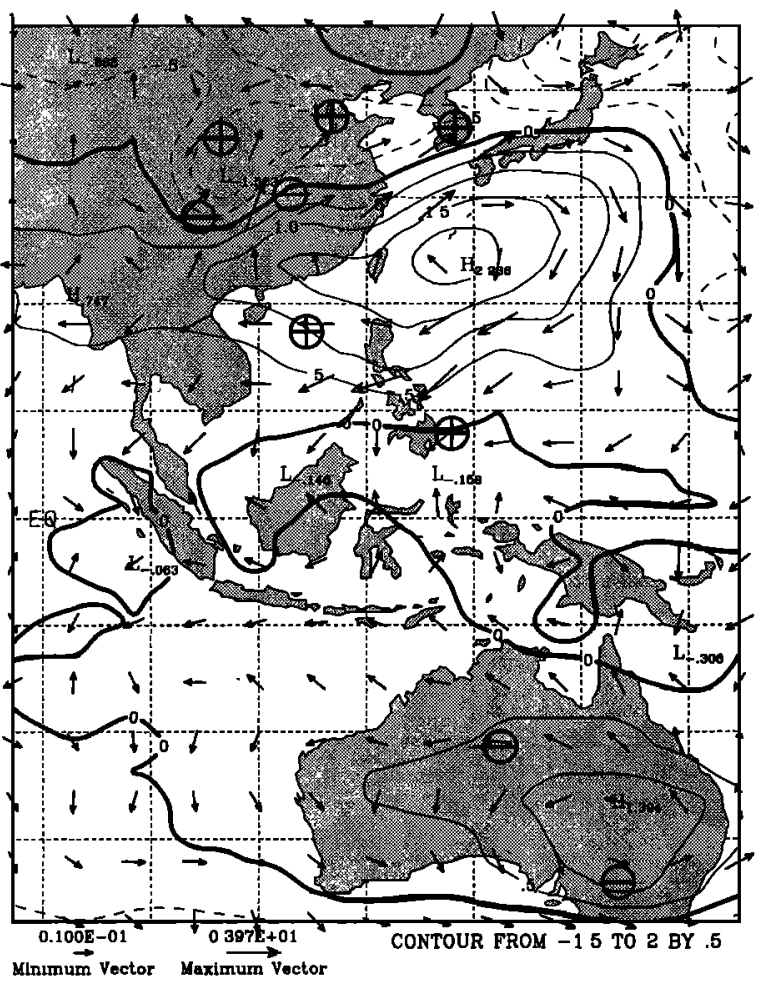

Figure 18. Surface pressure difference (contours, hPa) between NSIS and CNT, difference velocity (arrows, $\mathrm{m} \mathrm{s}^{-1}$ ) at $\sigma=0.970$, and statistically significant difference centers of ascent (pluses) and descent (minuses) at $\sigma=0.695$. The contour interval is $0.5 \mathrm{hPa}$. The thick contour is 0 .

southwest of Japan. Ascent anomalies are located along the rain front near about $35^{\circ} \mathrm{N}$ with subsidence anomalies about $7^{\circ}$ to the south. This suggests that the September link between the SH and the Asian monsoon can occur from lowlevel outflows from two anomalous highs, on opposite sides and each centered more than $20^{\circ}$ of latitude from the equator, that combine to form low-level convergence and middle tropospheric ascent near $8^{\circ} \mathrm{N}, 128^{\circ} \mathrm{E}$.

\subsection{Initial Response}

One of the immediate questions is how the signal propagates from high latitudes to lower latitudes and across the equator. Numerous studies have shown that the global atmospheric circulation is very sensitive to tropical forcing [e.g., Hoskins and Karoly, 1981; Yang and Webster, 1990]. Recent studies have also found the ENSO signal in sea-ice extent, temperature, precipitation, zonal wind, and other fields near and over Antarctica [Smith and Stearns, 1993; Gloersen, 1995; Cullather et al., 1996; Chen et al., 1996]. Whether the high latitudes, however, merely act as passive receivers or have significant feedbacks on global climate could not be determined by these studies. In this extreme sea-ice anomaly experiment, however, significant global influences have been found to result from the modified high-latitude forcing.

To understand how the effect of the sea-ice removal in NSIS is propagated through the atmosphere, we can look at the eddy flux during the early stages of the numerical experiments. The simulation begins during September, roughly the time of maximum sea-ice extent. Consequently, the differential initial forcing between NSIS and CNT is relatively large. The climatology of the eddy activity for the middle and high latitudes of both hemispheres is discussed here in terms of the two-dimensional (meridional and vertical) Eliassen-Palm (EP) flux that is defined by Edmon et al. [1980]:

$$
\mathbf{E P}=\left\{\overline{\left[u^{*} v^{*}\right]}, \overline{f_{0}} \overline{\left[v^{*} \theta^{*}\right] / \Theta_{p}}\right\}
$$

where symbols are conventional: the $u, v$, and $\theta$ are zonal wind, meridional wind, and potential temperature; $f_{0}$ is Coriolis parameter at $45^{\circ} ; \theta_{p}$ is associated with globally averaged static stability; the asterisks denote deviations from the zonal means; and overbars stand for time averages. The time-averaged zonally deviated eddy fluxes of momentum and heat are calculated on the basis of twice daily instantaneous outputs of CNT and NSIS. The initial spin-up processes are examined here in terms of the two-dimensional EP flux to show the eddy (departure from zonal mean) anomalies propagating to the lower latitudes. Figure 19 displays the EP flux and its divergence averaged for the initial month (September) of CNT and the anomalies between NSIS and CNT of the EP flux and its divergence averaged for days $1-10,11-20$, and $21-30$ of that month.

The basic pattems in Figure 19 illustrate that there are two major wave guides that direct eddy energy upward from the surface at latitudes between $50^{\circ}-65^{\circ}$ and then toward the equator and pole in the middle and upper troposphere of each hemisphere. Because the horizontal component of the EP flux is proportional to the horizontal eddy momentum flux and the vertical component of the EP flux is related to the horizontal eddy heat flux, the distribution of the EP flux expresses the fact that the eddy heat flux transport is poleward with a maximum in the lower troposphere and the eddy momentum flux transport is poleward in the low to middle latitudes and equatorward at high latitudes in the middle to upper troposphere. The direction of the EP flux shows the relative importance of eddy forcing on the mean flow by heat flux and by momentum flux. The EP flux is an effective tool for understanding the impact of eddy processes in middle and high latitudes but not in the tropics.

The signature of wave propagation can be observed from Figures 19b-19d during the initial model integration. In the first 10 days, averaged anomalies of EP flux and divergence are concentrated in southern high latitudes. Strong downward EP flux in the free atmosphere over Antarctica and downward (northward) EP flux in middle-high latitudes indicate anomalies of equatorward eddy heat (poleward eddy momentum) flux induced by sea-ice anomalies over high latitudes. There are only small dipole centers over northern high latitudes near the surface with upward EP flux anomalies. For days 11-20, the anomalies of eddy activity have spread and have been enhanced globally along the wave guide. The anomalies of the EP flux convergence in the middle troposphere have reached nearly half the magnitude of the EP flux convergence in CNT. The prominent impact on the NH eddies can be clearly observed in the anomalous difference in both the EP flux and its divergence during the average from days 21 to 30 (Figure 19d). The anomalies of the EP divergence show a wave pattern along the wave guide with nearly the same magnitude as the divergence itself.

These large-scale eddy adjustment processes would initiate a strong interaction between the eddy and mean flows and 

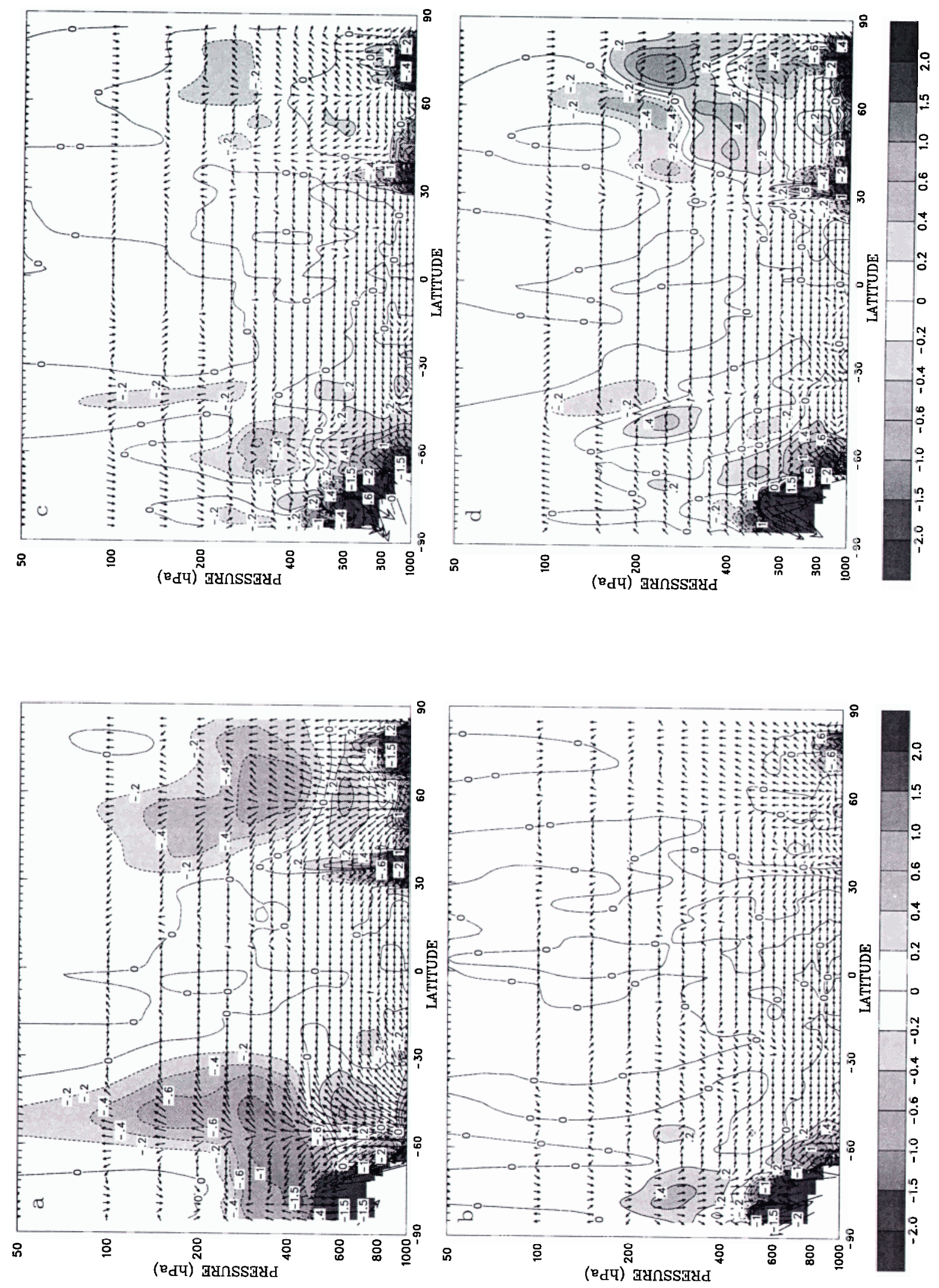

壱它 글 䛼总 递实诖 颌 대용 등 短 E. . . 3

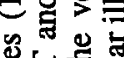
惓要

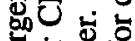

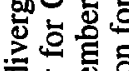

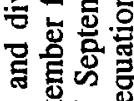
急部 悆 㐘.00

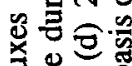

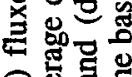
空 急家 톨 ब远

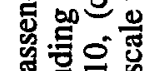
g

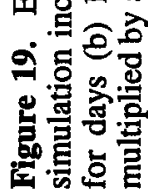


change the polar front jet [Trenberth, 1991] and the subtropical jet [Held and Phillips, 1990; B. Chen and L. R. Panetta, preprint, 1995] as well as the mean meridional circulation. The direct thermal modification of wave activity takes place near the storm track by low-level heat fluxes over the sea-ice removal area, so that the polar mean flow is drastically altered. Anomalies in wave activity would propagate along the major wave guide from high latitudes to the subtropical region. Then significant changes in the mean flow of lower latitudes by eddy-mean flow interactions could lead to the anomalies of precipitation and diabatic heating in the tropics. Once the perturbations are excited in the tropics, the associated changes in the $\mathrm{NH}$ are understandable on the basis of extensive prior work [e.g., Lau and Nath, 1994; Hou, 1998] through Rossby wave propagation and the mean meridional circulation. It takes less than a month for the disturbances propagating from southern high latitudes to reach the north pole and effectively modify the global mean flow through atmospheric internal dynamical processes. However, the relative influence of transient and stationary waves or high- and low-frequency waves on the mean flow in the simulation is not clear and needs further examination.

\section{Summary}

Simulations with the NCAR CCM2, including seasonal varying forcing, examine the greatest impact that removal of SH sea ice could have on the atmospheric circulation. Global and regional impacts induced by the replacement of Antarctic sea ice with year-round open water can be briefly summarized as follows.

1. The regional atmospheric responses in July (austral winter) to removal of Antarctic sea ice are similar to those in perpetual simulations $[S B]$ in many ways. As expected, the largest simulated changes occur adjacent to the coast of Antarctica. There are reductions in precipitation and pressure rises to the north of the sea-ice edge and increases in precipitation and pressure falls over the former sea-ice region. A new finding here is that the nature of the precipitation changes such that there are an increased convective component and a reduced large-scale component.

2. Substantial changes in pressure, vertical circulation, and precipitation extend into the middle latitudes of the NH. Changes are more significant in the SH during MaySeptember and more notable in the NH during AugustNovember, including the time of maximum SH sea-ice extent. The mean meridional circulation and convective precipitation in low latitudes have a modulation of about 5-10\%. Although the low-level temperatures over the southern high latitudes can be explained by the surface heat flux anomalies, the anomalies in the NH are more difficult to understand.

3. A train of positive and negative anomalies in the troposphere extends northward from southern high latitudes in both mean and eddy fields. These anomaly patterns in zonal wind, which are associated with anomalies of temperature, result in the southem polar front jet tending to merge with the subtropical jet in the upper troposphere and decreasing high-latitude low-level easterlies.

4. The removal of Antarctic sea ice results in September large-scale precipitation located farther to the north over China, especially along the coast. This agrees closely with the findings of Peng and Domrös [1987] that the extent of Antarctic sea ice is correlated with northem China precipitation and river runoff. The westward migration of the subtropical western Pacific high is also consistent with Peng and Domrös's findings that the location of the high is correlated to the extent and distribution of Antarctic sea ice. Thus the results of our extreme sea-ice experiment can be related to variations in the modern climate. As Simmonds and Jacka [1995] have noted, Peng and Domrös used a 10-year data set with an overall trend in sea-ice extent over that period. It would be interesting to see the correlation between the monsoon and sea ice reevaluated now that longer-term data sets are available.

5. Spin-up processes indicate that the wave anomalies excited by removal of Antarctic sea ice can propagate into the NH within a month. The anomalies in wave activity would propagate along the major wave guide from southern high latitudes to subtropical regions. Then significant changes in the mean flow of lower latitudes by eddy-mean flow interactions would lead to the anomalies of precipitation and diabatic heating in the tropics. Once the perturbations are excited in the tropics, the associated changes in middle and high latitudes of the NH would be completed by Rossby wave propagation along great circle trajectories and by the mean meridional circulation.

Acknowledgments. The work was supported by NASA grant NAGW-2718. The computations were mainly performed on the CRAY Y-MP of the Ohio Supercomputer Center; we thank Charles Bender for the grant of substantial computer time from the Director's Discretionary Fund. We would also like to thank Qiu-shi Chen for valuable discussions and three anonymous reviewers for their helpful comments. This is contribution 1071 of the Byrd Polar Research Center.

\section{References}

Andreas, E. L., and B. Murphy, Bulk transfer coefficients for heat and momentum over leads and polynyas, J. Phys. Oceanogr., 16, 1875-1883, 1986.

Bromwich, D. H., R.-Y. Tzeng, and T. R. Parish, Simulation of the modern Arctic climate by the NCAR CCM1, J. Clim., 7, 10501069, 1994.

Bromwich, D. H., B. Chen, and R.-Y. Tzeng, Arctic and Antarctic precipitation simulations produced by the NCAR community climate models, Ann. Glaciol., 21, 117-122, 1995.

Bromwich, D. H., B. Chen, K. M. Hines, and R. I. Cullather, Global atmospheric responses to Antarctic forcing, Ann. Glaciol., 27, in press, 1998.

Carleton, A. M., Sea ice-atmosphere signal of the Southern Oscillation in the Weddell Sea, J. Clim., 1, 379-388, 1988.

Carleton, A. M., Antarctic sea-ice relationships with indices of the atmospheric circulation of the southern hemisphere, Clim. Dyn., 3, 207-220, 1989.

Chen, B., D. H. Bromwich, K. M. Hines, and X. Pan, Simulations of the 1979-1988 polar climates by global climate models, Ann. Glaciol., 21, 83-90, 1995.

Chen, B., S. R. Smith, and D. H. Bromwich, Evolution of the tropospheric split jet over the South Pacific Ocean during the 1986-1989 ENSO cycle, Mon. Weather Rev., 124, 1711-1731, 1996.

Chiu, L. S., Antarctic sea ice variations 1973-1980, in Variations in the Global Water Budget, edited by A. Street-Perrott, M. Beran, and R. Ratcliffe, pp. 301-311, D. Reidel, Norwell, Mass., 1983.

Cullather, R., D. H. Bromwich, and M. Van Woert, Interannual variations in Antarctic precipitation related to El Niño-Southern Oscillation, J. Geophys. Res., 101, 19,109-19,118, 1996.

Domrös, M., and G. Peng, The Climate of China, 351 pp., SpringerVerlag, New York, 1988.

Edmon, H. J., B. J. Hoskins, and M. E. McIntyre, Eliassen-Palm cross-sections for the troposphere, J. Atmos. Sci., 37, 2600-2616, 1980.

Fletcher, J. O., Ice extent on the Southern Ocean and its relation to world climate, $R M-5793-N S F$, The RAND Corp., Santa Monica, Calif., 1969. 
Gloersen, P., Modulation of hemispheric sea-ice cover by ENSO events, Nature, 373, 503-506, 1995.

Glowienka-Hense, R., GCM response to an Antarctic polynya, Contrib. Atmos. Phys., 68, 303-317, 1995.

Hack, J. J., B. A. Boville, B. P. Briegleb, J. T. Kiehl, P. J. Rasch, and D. L. Williamson, Description of the NCAR community climate model (CCM2), NCAR Tech. Note, NCARTN-382+STR, 108 pp., Natl. Cent. for Atmos. Res., Boulder, Colo., 1993.

Hack, J. J., B. A. Boville, J. T. Kiehl, P. J. Rasch, and D. L. Williamson, Climate statistics from the National Center for Atmospheric Research community climate model CCM2, J. Geophys. Res., 99, 20,785-20,813, 1994.

Hanna, E., The role of Antarctic sea ice in global climate change, Prog. Phys. Geog., 20, 371-401, 1996.

Held, I. M., and B. J. Hoskins, Large-scale eddies and the general circulation of the troposphere, in Issues in Atmospheric and Oceanic Modeling, Part A: Climate Dynamics, edited by $\mathrm{S}$. Manabe, Adv. Geophys., 28, 3-31, 1985.

Held, I. M., and B. J. Phillips, A barotropic model of the interaction between the Hadley cell and a Rossby wave, J. Atmos. Sci., 47, $850-869,1990$.

Horel, J. D., and J. M. Wallace, Planetary-scale atmospheric phenomena associated with the Southern Oscillation, Mon. Weather Rev., 109, 813-829, 1981.

Hoskins, B. J., and Karoly, D. J., The steady linear response of a spherical atmosphere to thermal and orographic forcing, J. Atmos. Sci., 38, 2150-2163, 1981.

Hou, A. Y., Hadley circulation as a modulator of the extratropical circulation, J. Atmos. Sci., 55, in press, 1998.

Intergovernmental Panel on Climate Change, Climate Change 1995: The Science of Climate Change, edited by J. T. Houghton et al., Cambridge Univ. Press, New York, 1996

James, I. N., The Antarctic drainage flow: Implications for hemispheric flow on the southern hemisphere, Antarct. Sci., 1, 279-290, 1989

Karoly, D., Southern hemisphere circulation features associated with El-Niño Southern Oscillation events, J. Clim., 2, 1239-1252, 1989.

Kiehl, J. T., Sensitivity of a GCM climate simulation to differences in continental versus maritime cloud drop size, J. Geophys. Res., 99, 23,107-23,115, 1994.

Kiladis, G. N., and K. M. Weickmann, Extratropical forcing of tropical Pacific convection during the northern winter, Mon. Weather Rev., 120, 1924-1938, 1992.

Knutson, T. R., and K. M. Weickmann, 30-60 day atmospheric oscillations: Composite life cycle of convection and circulation anomalies, Mon. Weather Rev., 115, 1407-1436, 1987.

Ko, K.-C., and D. G. Vincent, Behavior of one- to two-week subtropical wind maxima over the South Pacific during an ENSO cycle, J. Clim., 9, 5-16, 1996.

Lau, K.-M., and P. H. Chan, Aspects of the 40-50 day oscillation during the northern hemisphere winter as inferred from outgoing longwave radiation, Mon. Weather Rev., 113, 1889-1909, 1985.

Lau, N.-C., and M. J. Nath, A modeling study of the relative roles of tropical and extratropical SST anomalies in the variability of the global atmosphere-ocean system, J. Clim., 7, 1184-1207, 1994.

Lubin, D., B. Chen, D. H. Bromwich, R. C. J. Summerville, W.-H. Lee, and K. M. Hines, The impact of Antarctic cloud radiative properties on a GCM climate simulation, J. Clim., 11, 447-462, 1998.

Mitchell, J. F. B., and C. A. Senior, The Antarctic winter: Simulations with climatological and reduced sea-ice extents, $Q . J$. R. Meteorol. Soc., 115, 225-246, 1989.

Mitchell, J. F. B., S. Manabe, T. Tokioka, and V. Meleshko, Equilibrium climate change, in Climate Change: The IPCC Scientific Assessment, edited by J. T. Houghton, G. J. Jenkins, and J. J. Ephraums, pp. 131-172, Cambridge Univ. Press, New York, 1990.

Oglesby, R. J., A GCM study of Antarctic glaciation. Clim. Dyn., 3, $135-156,1989$

Paegle, J. N., and K. C. Mo, Transient response of the southern hemisphere subtropical jet to tropical forcing, J. Atmos. Sci., 45, 1493-1508, 1988

Peng, G., and M. Domrös, Connections of the West Pacific
Subtropical High and some hydroclimatic regimes in China with Antarctic ice-snow indices, Meteorol. Atmos. Phys., 37, 61-71, 1987.

Rind, D., R. Healy, C. Parkinson, and D. Martinson, The role of sea ice in $2 \mathrm{X} \mathrm{CO}_{2}$ climate model sensitivity, I, The total influence of sea ice thickness and extent, J. Clim., 8, 449-463, 1995.

Rodwell, M. J., Breaks in the Asian monsoon: The influence of southern hemisphere weather systems, J. Atmos. Sci., 54, 25972611, 1997.

Simmonds, I., The effect of sea ice on a general circulation model of the southern hemisphere, in Sea Level, Ice and Climate Change, IAHS Publ. 131, 193-206, 1981.

Simmonds, I., and W. F. Budd, Sensitivity of the southern hemisphere circulation to leads in the Antarctic pack ice, $Q . J . R$. Meteorol. Soc., 117, 1003-1024, 1991.

Simmonds, I., and T. H. Jacka, Relationships between the interannual variability of Antarctic sea ice and the Southern Oscillation, $J$. Clim., 8, 637-647, 1995.

Smith, S. R., and C. R. Stearns, Antarctic pressure and temperature anomalies surrounding the minimum in the Southern Oscillation Index, J. Geophys. Res., 98, 13,071-13,083, 1993.

Trenberth, K. E., Storm tracks in the southern hemisphere, J. Atmos. Sci., 48, 2070-2087, 1991.

Tzeng, R.-Y., D. H. Bromwich, and T. R. Parish, Present-day Antarctic climatology of the NCAR community climate model version 1, J. Clim. 6, 105-226, 1993.

Tzeng, R.-Y., D. H. Bromwich, T. R. Parish, and B. Chen, NCAR CCM2 simulation of the modern Antarctic climate, J. Geophys. Res., 99, 23,131-23,148, 1994.

Wallace, J. M., and D. S. Gutzler, Teleconnections in the geopotential height field during the northern hemisphere winter, Mon. Weather Rev., 109, 784-812, 1981.

Washington, W. M., and G. A. Meehl, High-latitude climate change in a global coupled ocean-atmosphere-sea ice model with increased atmospheric $\mathrm{CO}_{2}$, J. Geophys. Res., 101, 12,795$12,802,1996$.

Washington, W. M., and C. L. Parkinson, An Introduction to ThreeDimensional Climate Modeling, 413 pp., Oxford Univ. Press, New York, 1986.

Webster, P. J., and J. R. Holton, Wave propagation through a zonally varying basic flow: The influences of midlattude forcing in the equatorial regions, J. Atmos. Sci., 39, 722-733, 1982.

Weickmann, K. M., and G. N. Kiladis, Circulation anomalies associated with tropical convection during the northern winter, Mon. Weather Rev., I20, 1900-1923, 1992.

$\mathrm{Wu}, \mathrm{G}$., and C. Brankovic, General circulation diagnostics package, ECMWF Res. Dep. Tech. Memo 96, Eur. Cent. for MediumRange Weather Forecasts, Reading, England, 1985.

Xie, S., C. Bao, and C. Hao, Study on the oscillation relationship between sea ice of the Arctic and Antarctic, Proc. NIPR Symp. Polar Meteorol. Glaciol., 8, 111-128, 1994a.

Xie, S., C. Bao, Z. Xue, L. Zhang, and C. Hao, Interaction between Antarctic sea ice and ENSO events, Proc. NIPR Symp. Polar Meteorol. Glaciol., 8, 95-110, 1994b.

$\mathrm{Xu}, \mathrm{J}$.-S., H. von Storch, and H. van Loon, The performance of four spectral GCMs in the southern hemisphere: The January and July climatology and the semiannual wave, J. Clim., 3, 53-70, 1990.

Xu, T., J. E. Walsh, and W. L. Chapman, An assessment of global climate model simulations of Arctic air temperatures, J. Clim., 9 , 1060-1076, 1996.

Yang, S., and P. J. Webster, The effect of summer tropical heating on the location and intensity of the extratropical westerly jet streams, J. Geophys. Res., 95, 18,705-18,721, 1990.

Zhang, C., and P. J. Webster, Laterally forced equatorial waves in mean zonal flow, I, Stationary transient forcing, J. Atmos. Sci., 49, 585-607, 1992.

D. H. Bromwich, B. Chen, and K. M. Hines, Polar Meteorology Group, Byrd Polar Research Center, Ohio State University, 108 Scott Hall, 1090 Carmack Road, Columbus, OH 43210-1002. (e-mail: bromwich@polarmet1.mps.ohio-state.edu)

(Received July 21, 1997; revised December 17, 1997; accepted February 18, 1998.) 